\title{
Epônimos e o consórcio intelectual entre ciência e literatura*
}

\author{
Rogerio F. Guerra \\ Universidade Federal de Santa Catarina
}

Alguns escritores recorrem ao conhecimento cientifico para descrever as doenças e enfermidades mentais de seus personagens. Tal procedimento melhora a qualidade literária dos textos, como atestam obras clássicas de Leon Tolstoi (A morte de Ivan Ilitch, 1886) e Thomas Mann (The black swan, 1953), por exemplo; alguns escritores brasileiros também descreveram distúrbios da personalidade, efeitos sociais de doenças tropicais e a gênese do fanatismo religioso (e.g., Lima Barreto, J. Guimarães Rosa e Euclydes da Cunha). Por outro lado, nomes de autores ou personagens fictícios às vezes são utilizados para designar doenças e fenômenos científicos (epônimos), como síndrome de Münchhausen ou de Stendhal, alucinações lilliputianas (Jonathan Swift), síndrome do Sr. Pickwick (Charles Dickens) e doença do chapeleiro maluco (Lewis Carroll). Boa ciência e boa literatura não são incompatíveis, mas o oposto é verdadeiro. Nós postulamos que textos literários podem ser usados para o treinamento de habilidades profissionais, uma vez que tais recursos permitem o aperfeiçoamento dos relatórios técnicos e amplia a capacidade observacional em relação aos sintomas de uma enfermidade,
Some writers have recurred to the scientific knowledge for describing diseases and mental disturbances of their characters. It appears that it improves the quality of literary texts, as may be seen in the classic novels by Leon Tolstoy (The death of Ivan Ilytch, 1886), and Thomas Mann (The black swan, 1953), for example; in our idiom, some Brazilian writers have described the personality disorders, social effects of tropical diseases and the genesis of fanatical rebellions (e.g., Lima Barreto, J. Guimarães Rosa and Euclydes da Cunha). On the other hand, authors and fictitious characters may be used for naming diseases and scientific phenomenon (eponyms), such as Münchhausen and Stendhal syndromes, Lilliputian hallucinations (Jonathan Swift), Mr. Pickwick syndrome (Charles Dickens) and mad hatter's disease (Lewis Carroll). Good science and good literature are not incompatible, but the opposite is true. We postulated that novels and poetry may be used for training professional abilities, since it makes better the writing of technical texts and improve the observational capacity regarding the symptoms of diseases,

\footnotetext{
* Eponyms and the relationship between science and literature

${ }^{1}$ Professor-Titular e Editor da Revista de Ciências Humanas. Endereço para correspondências: Universidade Federal de Santa Catarina, Departamento de Psicologia, Campus Universitário, Florianópolis, SC, 88040-970 (rfguerra@cfh.ufsc.br).
} 
assim como preserva a empatia dos profissionais dos serviços de saúde em relação ao sofrimento humano.

Palavras-chave: Ciência e literatura - Diários e biografias - Epidemias Doença mental - Epônimos as well as preserve the empathy of professionals from the health services on human suffering.

Keywords: Science and literature Diaries and biographies - Epidemics - Mental disturbances - Eponyms.

\title{
Introdução
}

\begin{abstract}
A s histórias de Sir Arthur Conan Doyle (1859-1930), o criador de Sherlock Holmes, exploram algo valioso no mundo da ciência: o raciocínio lógico indutivo. Doyle se formara em medicina na Universidade de Edimburgo e serviu como oficial-médico na Guerra dos Bôeres (1899-1902); ele escreveu um livro panfletário sobre a guerra na África do Sul (The war in South África, 1902), ganhando com isso o título de cavaleiro. A pobreza o levou a trocar o consultório médico pela carreira literária, dando vida às deliciosas histórias de Sherlock Holmes. O conhecido detetive formava uma dupla inesquecível com Dr. John H. Watson. Holmes tinha profundos conhecimentos em química e sabia bastante coisa sobre anatomia; ele não era possuidor de um título acadêmico formal, mas agia como se fosse um psicólogo forense. Por seu turno, Watson era um médico do Exército Britânico e atuara como cirurgião no $5^{\circ}$ Regimento de Fuzileiros, ocasião em que fora ferido nos campos de batalha e tivera o azar de contrair tifo quando se restabelecia num hospital na Índia.
\end{abstract}

A frase "elementar, meu caro Watson" é uma invencionice de seus admiradores, pois nunca fora proferida pelo detetive; ela serve para designar algo supostamente óbvio para uma mente privilegiada. Um exemplo do modo como a maquinaria cerebral de Holmes funcionava pode ser visto no capítulo Ciência da Dedução, da obra inicial de Doyle (A study in scarlet, 1887) ${ }^{2}$. É a ocasião em que o detetive aperta vigorosamente a mão de Watson e dispara: "- posso ver que você esteve no Afeganistão.” Diante do espanto de Watson, ele informa que uma seqüência de pensamentos se apoderou de sua mente e ele não se deteve no processo; foi algo rápido e ele não levou mais que dois segundos para extrair suas conclusões.

Os argumentos são interessantes e merecem detalhamento. Com efeito, Watson era um cavalheiro do tipo médico e com ares de militar. Tal dedução foi corroborada por dois fatos: ele tinha uma face amorenada, mas aquela cor não era natural, uma vez que, ao estender a mão para o aperto de mãos,

${ }^{2}$ Arthur Conan Doyle.Sherlock Holmes - Edição completa. Rio de Janeiro: Agir Editora, 2007. 
ele deixara exposto o pulso com cor mais clara. A palidez da face e o braço esquerdo, mantido numa posição rígida e pouco natural, revelavam que Watson estava ferido e fora exposto a condições de extrema fadiga e doenças. "Em que lugar poderia um médico inglês ter sido exposto a tantas adversidades?", pensou Holmes consigo mesmo. "É claro que foi no Afeganistão!", ele deduziu em seguida. Além de sabermos algo sobre esquemas indutivos de pensamento, as histórias do detetive nos ensinam que os ingleses mantinham missões militares no Afeganistão.

Como surgiu a idéia para a criação do inesquecível personagem? O detetive não foi criado ao acaso, pois Doyle informou que se inspirara nos traços de personalidade de Joseph Bell, médico-cirurgião do Hospital de Edimburgo e professor daquela universidade; ele e o seu detetive eram bem parecidos, no aspecto físico e sagacidade: ambos eram altos, andavam de modo desengonçado e tinham rostos angulosos e narizes avantajados. A partir de uma simples conversa e olhadela nos pacientes, Bell extraia as informações necessárias para o seu ofício, para espanto de seus alunos ${ }^{3}$. Sherlock Holmes era o que Doyle chamava de "detetive científico" e a sua atuação está de acordo com as modernas técnicas de investigação policial. Curiosamente, Bell deveria servir de modelo para criação de Watson, pois ambos eram médicos e tinham formação acadêmica regular, mas este simboliza a ciência convencional e desprovida de imaginação, enquanto Holmes é o gênio outsider que não se dobra aos rigores daquilo que conhecemos como "metodologia científica".

Doyle alcançou sucesso imediato, mas as infindáveis histórias o cansaram e, então, ele resolveu engendrar o "assassinato" de sua criatura; os leitores protestaram veementemente e ele foi forçado a providenciar o "ressuscitamento" do detetive. A dupla Holmes-Watson inspirou os personagens centrais da série televisiva "Os arquivos X": Fox Mulder (versão moderna de Holmes) é psicólogo forense com formação na Universidade de Oxford, enquanto Dana Scully (ou Dr. Watson) é médica patologista e atua de modo a enaltecer a inteligência e a sagacidade de seu parceiro; a diferença nas estaturas é marcante e Mulder parece fitar Scully tendo como referência uma linha imaginária acima da testa da parceira. O momento e as circunstâncias em que os dois são apresentados também repetem o que ocorre no capítulo inicial do livro de Doyle. Muitos imaginam que esquemas lógicos, o raciocínio matemático ou a complexidade do conhecimento científico não agradam aos leitores, mas outros exemplos apontam o contrário.

${ }^{3}$ Arthur Conan Doyle. Memórias e aventuras. São Paulo: Marco Zero, 1993. 


\section{Hümanas}

\section{As doenças}

Nos tempos heróicos de Vasco da Gama (c.1469-1524) as elevadas taxas de mortalidade nos navios eram ocasionadas pelo escorbuto, deficiência de vitamina $\mathrm{C}$ que resultava em perda dentária, sangramentos nas gengivas, hemorragias e gangrena nos antigos marinheiros. O navegador português descobriu a ligação dos oceanos Atlântico e Pacífico (Cabo da Boa Esperança, no Natal de 1497) e fora designado vice-rei da Índia (1524), mas morreu quase em seguida. Os feitos do herói português mereceram os versos de Luís de Camões (Os lusíadas, 1572), os quais descrevem os sintomas do escorbuto. Quando os navios demandavam os portos da Índia e "navegavam por mares nunca dantes navegados", o intrépido Vasco da Gama perdeu cerca de 100 homens, dentre 160. Os versos de Camões descrevem a desolação dos sobreviventes e são os primeiros registros do mal-de-Luanda:

E foi que de doença crua e feia,/ A mais que eu
nunca vi, desamparam
Muitas a vida, e em terra estranha e alheia/ Os os-
sos para sempre sepultaram.
Quem haverá que, sem o ver, creia?/ Que tão disfor-
memente ali lhe incharam
As gengivas da boca, que crescia/ A carne, e junta-
mente apodrecia
- Apodrecia e um fétido e bruto/ Cheiro, que o ar
vizinho inficionava;
Não tínhamos ali médico astuto,/ Cirurgião subtil
menos se achava:
Mas qualquer neste oficio pouco instructo/ Pela
carne já podre assim cortava,
Como se fora morta, e bem convinha,/ Pois que
morto ficava quem a tinha ${ }^{4}$.

Doenças e epidemias eram os grandes obstáculos para a ampliação dos domínios territoriais e realização de grandes obras de engenharia, como a construção do Canal do Panamá (1881-1914) que exigiu procedimentos inovadores de combate à malária. Os efeitos sociais da doença eram enormes, pois ela interferia negativamente na economia e impedia o funcionamento das instituições. A obra do mineiro J. Guimarães Rosa (1908-67) descreve a situação dos moradores de um fictício vilarejo que se transformara num santuário de mosquitos anofelinos; o escritor conhecia bem o assunto, pois era médico e nascera numa região flagelada pela doença. O conto Sarapalha (1946) se inicia com

\footnotetext{
${ }^{4}$ Luis de Camões. Os lusíadas. Canto V. Rio de Janeiro: Biblioteca do Exército, 1980.
} 
a descrição do vilarejo que fora "largado pelos moradores" em razão dos ataques das fêmeas do mosquito anofelino. Os personagens são Primo Argemiro, Primo Ribeiro, a velha Ceição e um cão sarnento, além de outros que povoavam os delírios ocasionados pela enfermidade. A conversa entre os dois homens é marcada por ranger de dentes e sensação de calafrios que se alternam com intensa sudorese - suas entranhas escondiam colméias de bichinhos malvados que, em dias alternados, liberavam enxames na corrente sangüínea. A história é curta e pode ser lida num só fôlego, mas ela descreve com precisão as complicações clínicas e sociais decorrentes de uma epidemia de malária. A leitura até permite suspeitar que Primo Argemiro e Primo Ribeiro eram vítimas das picadas do Plasmodium falciparum, o agente patogênico que provoca a forma mais grave da enfermidade. Em certo momento, eles trocam impressões sobre suas desgraças:

- Olha o frio aí, Primo Argemiro... Me ajuda...

Enrola-se mais no cobertor. Os dentes se golpeiam.

Desencontrados, dançam-lhe todos os músculos do corpo.

- Quer o remédio, Primo?

- Não vou tomar mais... Não adianta. Está custando muito a chegar a morte... E eu quero é morrer.

Primo Argemiro se agarrou com as mãos nos joelhos. Os maxilares estrondam; só param de bater quando ele faz vômito. E está cor de cera-doreino quando pega a derreter.

- Ai, Primo Argemiro, eu, numa hora dessas... só queria era me deitar em beira de um fogueirão!... Que frio... Que frio!... E o diabo do sol que não quenta coisa nenhuma... (pp. 162-3)

Alguns escritores fizeram descrições detalhadas sobre as perturbações mentais sofridas por seus personagens, como Fiodor Dostoievsky (1821-81). Ele sofria de epilepsia e parece que utilizara os sinais da própria enfermidade para compor os enredos de O idiota (1866) e Os irmãos Karamazov (1880). Os personagens de Shakespeare sofrem de sonambulismo, apnéia noturna, insônia e pesadelos; ele descreveu crenças antigas acerca da epilepsia, lábio leporino, cárie dentária (um verme que corroia os dentes a partir do interior) e histeria (ver DYER, 1978). Uma análise de Richard II e Henry IV (partes I e II) indicam que ele conhecia bem a relação entre sonolência diurna e obstrução respiratória, mas quem mais avançou na descrição desse distúrbio foi Charles Dickens (1812-70), escritor inglês e leitor contumaz de The Lancet, a centenária revista inglesa de medicina (FURMAN et al., 1997; WHITELAW \& BLACK, 2000).

${ }_{5}^{5}$ J. Guimarães Rosa. Sagarana. 63 ${ }^{a}$ Edição. Rio de Janeiro: Nova Fronteira, 2001. 


\section{HUMANAS}

Distúrbios do sono e fenômenos psicopatológicos pouco conhecidos foram examinados por autores consagrados, como Leon Tolstoi, A.P. Tchekhov e Lewis Carroll. A obra do espanhol Miguel de Cervantes também descreve perturbações mentais e alguns distúrbios do sono. Com efeito, em Don Quixote de la Mancha (1605-15) o personagem homônimo têm delírios, pensamentos obsessivos e acredita ser um cavaleiro medieval errante, em luta constante contra moinhos de vento. Ele sofria de insônia crônica, dificuldades no sono REM e sonolência pós-prandial, algo que o levava às siestas. Don Quixote também roncava alto (indício de hipoventilação pulmonar), o que dificultava a entrada no sono profundo; a obsessão pelo amor de Dulcinéia dificultava o sono e a insônia crônica alimentava a sua loucura (IRANZO et al., 2004).

\section{Diários e relatórios}

Algumas obras descrevem momentos históricos e os eventos vividos por seus autores. Elas contêm os elementos que caracterizam um relatório científico (precisão, clareza e fidedignidade) e aqueles que atendem às necessidades de um bom leitor (i.e., uma história interessante). A linguagem precisa é condizente com a boa literatura, como atestam as produções literárias de Euclydes da Cunha (Os sertões: campanha de Canudos, 1902) e M.B. Lourenço Filho (Juazeiro do Padre Cícero, 1926); outro exemplo interessante é a obra do russo Alexander Solzhenitsyn (Arquipélago Gulag, 1973-78), a qual descreve realisticamente os horrores do sistema penal soviético. Alguns intelectuais mantinham diários ou deixaram impressões autobiográficas relevantes, como Virginia Woolf, Anne Frank e Franz Kafka; esses registros eram comuns entre os militares e exploradores, mas algumas intelectuais descreveram a vida cotidiana das mulheres de outros tempos (ver PAPERNO, 2004; McKAY, 2005). As contribuições de Samuel Pepys (1633-1703) e Daniel DeFoe (1660-1731) são as mais interessantes para os nossos propósitos e serão examinadas a seguir.

O escritor inglês Daniel DeFoe fez uma descrição detalhada sobre estatística e evolução da peste bubônica em Londres. O seu conhecido livro ( $A$ journal of the plague year, 1722) foi escrito de moda claro e objetivo; o journal continha tabelas e informações estatísticas e muitos entenderam que eram os anúncios do nascimento do moderno jornalismo. Em meados do século 14, a peste havia se espalhado pela Europa, ocasionando a morte de milhões de pessoas (cerca de S! da população, nas áreas afetadas); os graves efeitos da epidemia foram registrados por Bocaccio (Decameron, 1358). Focos da doença surgiam e ressurgiam, sem que os habitantes tivessem idéia precisa acerca dos fatores causais de suas tragédias. Trata-se de uma doença infecciosa transmitida pelo bacilo Yersinia pestis, com período de incubação de 3 a 6 dias. 
Ela é caracterizada por febres, calafrios, vômitos, dores no corpo e gânglios (bubões, daí o nome peste bubônica) que aparecem na virilha e axilas. $\mathrm{O}$ bacilo era transmitido pelas pulgas dos ratos aos cães e gatos, destes para as pessoas.

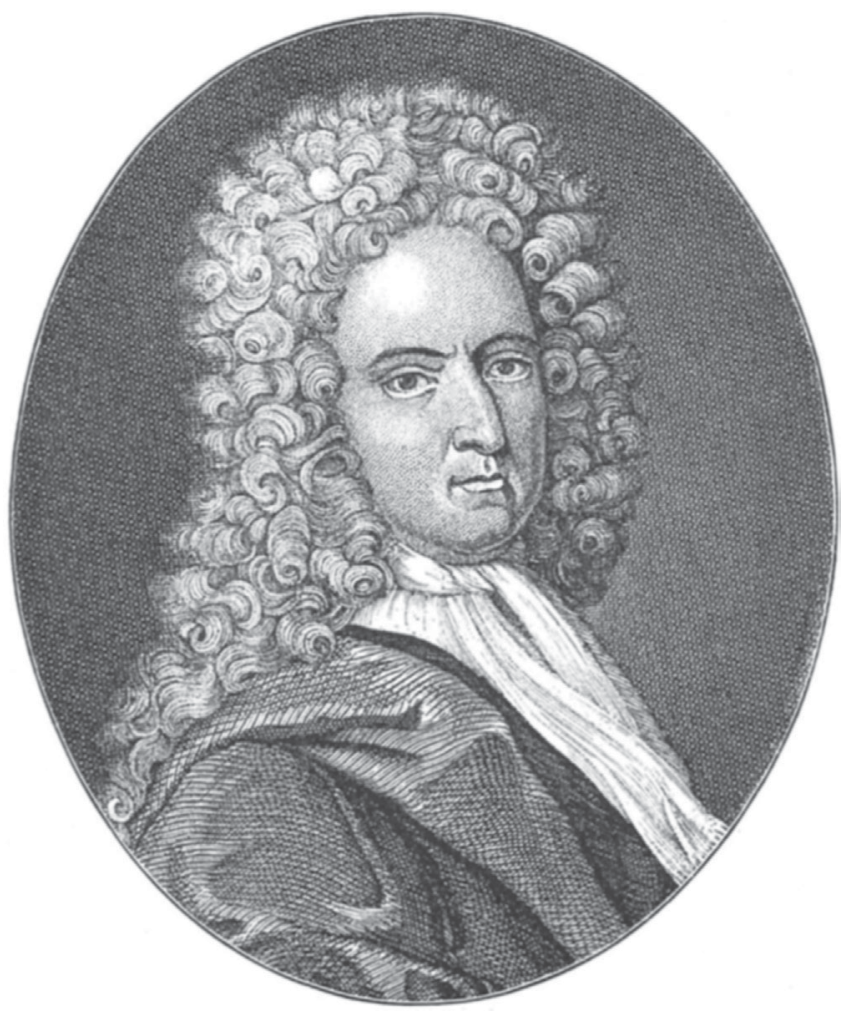

Figura 1

Daniel DeFoe (1660-1731), romancista inglês mais conhecido por Robinson Crusoe (1719) e Moll Flanders (1722). Ele descreveu vividamente os efeitos de uma epidemia de tifo sobre a população (A journal of the plague year, 1722), obra que se revelou de grande significado histórico e científico.

Os habitantes de Londres viviam imersos em crendices e julgavam que a peste era o castigo de Deus para as falhas humanas; alguns se lembravam de um cometa que surgira nas noites de Dezembro/1664, outros recorriam à numerologia bíblica para explicar as elevadas taxas de mortalidade no ano 1666 (os três últimos numerais sinalizavam o império da Besta, Apc 13:18). Algumas crenças curiosas explicavam que a doença era ocasionada pelos odores fétidos ou "ar parado", de modo que muitos se besuntavam de perfumes para evitar as contaminações e bimbalhavam os sinos das igrejas ou soltavam tiros de canhões para movimentar os ares pestilentos (ZIEGLER, 1991; SUTCLIFFE \& DUIN, 1992; BELL, 2001). 
A peste bubônica emergiu nos anos 1664-65 e ocasionou cerca de 75.000 mortes, enquanto que a população londrina não ultrapassava a 460.000 habitantes; esses números são subestimados, pois a epidemia prejudicou o funcionamento das instituições públicas, os próprios familiares se encarregavam dos sepultamentos e não havia muito tempo para os registros estatísticos.

Os mortos eram contados aos milhares e os coveiros se cercavam de cuidados no exercício da horrenda tarefa; eles abriam valas enormes e, com o auxílio de varas e ganchos, puxavam os cadáveres, sempre cuidando para manter uma posição a favor dos ventos. Alguns espertalhões se apoderavam das mortalhas para revenda e os carroceiros recolhiam indivíduos ainda pertencentes ao mundo dos viventes (he's not yet dead!) - os recolhimentos eram realizados sem remorso algum, pois eles sabiam que a morte não tardaria. Os enfermos eram trancafiados dentro de suas residências, junto com os demais familiares, saudáveis ou não, e permaneciam entregues à própria sorte; as autoridades sinalizavam a quarentena com uma enorme cruz vermelha pintada nas portas, acompanhada de uma súplica: Lord have mercy upon us! Os sepultamentos eram realizados sem a mínima decência e enfermeiras desalmadas ou os próprios familiares apressavam a morte daqueles que eles julgavam estar em estado terminal. A descrição do not yet dead até hoje causa forte impressão, como atestam o humor negro do Monty Python e nomes de certas bandas de rock'n roll. Muitos temiam os contatos com estranhos, mas viviam numa promiscuidade junto aos seus cães e gatos, até o momento em que as autoridades foram forçadas a implantar algumas medidas sanitárias. $\mathrm{O}$ mecanismo de transmissão da doença não era conhecido, mas as autoridades intuitivamente percebiam que as deploráveis condições higiênicas eram fatores relevantes nessas tragédias. Assim sendo, incontáveis cães e gatos foram sacrificados, mas, curiosamente, os moradores não se preocupavam com a proliferação de ratos. O estado emocional dos londrinos foi assim descrito:

Naquele tempo, conforme aumentava a devastação, também crescia o pavor das pessoas, que faziam mil coisas indescritíveis, movidas pela fúria de seu medo, enquanto outras faziam o mesmo na agonia da doença. Isso foi muito impressionante. Alguns saíam gemendo pelas ruas, chorando e contorcendo as mãos. Outros rezavam erguendo as mãos ao Céu, pedindo misericórdia a Deus (p. 121) .

DeFoe escreveu A journal of the plague year (1722) dando a entender que ele fora testemunha ocular ou que tivesse colhido depoimentos das vítimas da tragédia, daí induzindo a crer que a obra marcava o nascimento do jornalismo.

${ }^{6}$ Daniel DeFoe. Um diário do ano da peste. Porto Alegre: Artes e Ofícios, 2002. 
Tal idéia deve ser examinada com cuidado, pois o seu journal é uma obra ficcional - a peste flagelou Londres nos anos 1665-66 e ele na ocasião tinha apenas 5 ou 6 anos de idade. Entretanto, parece que DeFoe recorreu aos registros oficiais e colheu depoimentos de alguns sobreviventes para fornecer detalhes bastante realísticos sobre a situação dos moradores de Londres. $\mathrm{O}$ surto de peste bubônica foi gradativamente perdendo intensidade, mas a eliminação dos focos patogênicos foi ocasionada por outra tragédia: o incêndio de Londres (2 a 6 de Setembro/1666).

O terrível incêndio teve início acidental numa padaria de Pudding Lane e foi o pior da história de Londres. As chamas atingiram 160 hectares $(80 \%$ da cidade) e transformaram em cinzas cerca de 13.000 moradias, 89 igrejas, incluindo a imponente catedral de São Paulo, e a maior parte dos prédios públicos. O número de mortos foi surpreendentemente baixo (20 pessoas), mas os rios ficaram atulhados de barcos que transportavam os moradores com seus pertences. O fogaréu teve início numa segunda-feira e não deu tréguas no dia seguinte, graças aos ventos que espelharam as chamas pela cidade. Na quarta-feira, o incêndio perdeu intensidade e quase se extinguiu no dia seguinte, mas as chamas foram reavivadas ao anoitecer, para desespero dos moradores que assistiam a cena nas colinas da cidade; as pessoas perderam todos seus haveres e sequer tinham onde se abrigar. $\mathrm{O}$ incêndio de Londres foi descrito vividamente por Samuel Pepys (1633-1703) ${ }^{7}$, ex-presidente da veneranda Royal Society (1684-86) que usufruía da amizade de Sir Isaac Newton e Robert Hooke.

Os diários de Samuel Pepys descrevem o período de 1 de Janeiro/1660 a 31 de Maio/1669, ano em que o diarista perde a esposa e começa a exibir sérios problemas visuais. Seus relatos são abrangentes e foram escritos numa linguagem cifrada, mas foram decodificados e publicados em 1825. Pepys descreveu o desespero dos habitantes, ocasionado pelo surto de peste bubônica (1665-66) e o terrível incêndio que açoitara a cidade. A primeira catástrofe ceifou cerca de $20 \%$ da população de Londres e o incêndio, transformou em cinzas as casas de madeira dos moradores pobres. Os diários também descrevem as impressões do autor, no momento em que ele próprio é submetido a uma cirurgia para extração de pedras na bexiga (litotomia); os relatos chamam a atenção dos especialistas, uma vez que Pepys descreve o modo como a cirurgia foi realizada e a evolução do quadro clínico (ver URQUHART-HAY, 1999; WILSON et al., 2002; KUMAR \& NARGAND, 2006).

O diarista compulsivo tinha interesse variado, abrangendo desde o alastramento de epidemias, a inflamação que ele tivera nos olhos, dissecações anatômicas, transfusão sanguínea e episódios da história de seu país.

${ }^{7}$ Everybody's Pepys. Nova York: Harcourt, Brace \& Co., 1926. 
Os especialistas ficaram impressionados com as descrições do forte abalo emocional dos moradores diante do incontrolável fogaréu. Os sinais e sintomas eram de uma genuína enfermidade mental, reconhecida como a "síndrome do grande incêndio de Londres", referência aos relatos minuciosos de Pepys. Trata-se de uma perturbação mental exibida por pessoas que vivenciam, direta ou indiretamente, catástrofes naturais, guerras ou acidentes violentos de grandes proporções. O distúrbio passou a ser conhecido como "neurose de guerra" ou "síndrome do sobrevivente", mas o comitê do DSM-III (1980) reconheceu a especificidade do distúrbio e deu-lhe novo nome: Posttraumatic stress disorder (PTSD).

A epidemia de tifo e o colossal fogaréu trouxeram benefícios aos moradores de Londres, pois alertaram as autoridades acerca das precárias condições de vida; não havia mais espaço para "ira divina" e os espíritos pragmáticos acordaram para o saneamento básico e planejamento ambiental. Do ponto de vista científico, ocorreu algo de grande relevância. As instituições acadêmicas fecharam as portas e o jovem Isaac Newton teve que buscar refúgio na fazenda de seus familiares, em Lincolshire. Ele contava com 23 anos, havia se formado no Trinity College e pretendia ingressar no Master of Arts (MA, equivalente ao nosso Mestrado), mas aproveitou o retiro forçado para realizar experimentos em química e prismas, os quais o levaram a concluir que a luz branca é uma composição de cores. As especulações matemáticas germinavam em sua mente, ele efetuou melhorias nos telescópios e chegou aos princípios básicos das leis da mecânica e da teoria gravitacional; suas descobertas deram origem aos livros Philosophiae naturalis principia mathematica (1687) e Opticks (1704). Todos esses avanços ocorreram nos dois anos que ele viveu isolado entre as vacas e os cavalos da fazenda. Em suas memórias, Newton relembra os dois anos em que Londres fora flagelada pela peste e incêndio (1665-66), anos que ele considera os melhores de sua vida ${ }^{8}$.

Doenças infecto-contagiosas serviram de tema para as obras de A.P. Tchekhov, Thomas Mann e Graciliano Ramos; o assunto também despertou as atenções de Albert Camus. Os esforços de erradicação da peste só começaram a surtir efeitos positivos a partir de uma epidemia ocorrida em Hong Kong (1894), ocasião em que foi identificado o bacilo Pasteurella pestis (nome inicial da Yersinia pestis) e ficou estabelecido o modo como as pulgas dos ratos transmitiam a doença ao ser humano (SUTCLIFFE \& DUIN, 1992). A efemeridade da vida e a íntima convivência com a morte (os enfermos geralmente morriam em casa, ladeados pelos familiares) promoveram uma forma de manifestação artística, a dance macabre e ars moriendi. Trata-se da representação alegórica de uma dança ou procissão na qual a morte visita os

${ }^{8}$ The Oxford English reference dictionary. Oxford: Oxford University Press, 1995. The Cambridge Biographical Encyclopedia. Cambridge: Cambridge University Press, 1998. 
viventes para conduzi-los ao juízo final. A peste flagelou a Europa medieval e as pessoas morriam de modo miserável e, portanto, os artistas julgavam adequado representar a morte na forma de uma velha feiíssima, cujo aspecto tenebroso era acentuado com a indumentária preta e a inseparável foice. Pouco se conhecia sobre a origem da doença, mas todos tinham como certo que as mortes horrendas resultavam de um combate travado entre os anjos e as forças demoníacas. A dance macabre inspirou as gravuras de Hans Holbein (1538) e até um filme do cineasta Ingmar Bergman (O sétimo selo, 1956).

\section{O sofrimento humano}

Escritores e profissionais dos serviços de saúde lidam rotineiramente com o sofrimento humano, mas de forma diferente. Enquanto os primeiros ruminam longamente as dores do espírito e usam tais elementos em suas composições literárias, médicos, enfermeiros e psicólogos lidam diretamente com a morte e o sofrimento humano, mas mantêm certo distanciamento emocional de seus pacientes. Isso não significa que eles sejam insensíveis aos infortúnios alheios, mas é apenas uma tentativa de evitar que o estresse e o burnout interfiram negativamente na eficiência do atendimento. Entretanto, os profissionais dos serviços de saúde poderiam cultivar a sensibilidade emocional através da literatura, seja para treinar a compreensão dos sinais e sintomas de uma enfermidade ou para manter a devida empatia em relação ao sofrimento humano. Essa idéia não é nova, pois a precisão e o valor dos registros literários foram atestados por especialistas que examinaram obras de autores consagrados, de Shakespeare à Thomas Mann (ver KACHAEVA, 1995; FURMAN et al., 1997; IRANZO et al., 2004; DIETL, 2004; VEIN, 2007).

Teorias e postulações científicas geralmente são fundamentadas em estudos amplos, os quais envolvem amostras representativas, análises estatísticas e condições de falseabilidade. Estudos de casos também encontram espaço nos periódicos científicos, mas eles são publicados de modo circunstancial. Por outro lado, algumas obras literárias exploram intensamente as idiossincrasias dos personagens, chegando a descrever detalhadamente os sintomas de perturbações mentais pouco conhecidas. Tais peculiaridades são encontráveis num dos livros de Fiodor Dostoievsky (Crime e castigo, 1866). Com efeito, o escritor russo descreve o envolvimento de Rodian Raskolnikov num terrível crime: o assassinato de uma senhora avarenta e de sua irmã. O personagem planejara matar a velha senhora para lhe roubar os pertences, mas o crime é testemunhado pela outra, de modo que as duas acabam sendo mortas com golpes de machado. Ele sofre uma intensa turbulência mental, antes e após o crime. Inicialmente, Raskolnikov tem delírios, dorme mal e gradativamente se transforma num zumbi; 
como geralmente ocorre na mente de um canalha, ele encontra justificativa para dar prosseguimento ao plano. Ele imagina que a morte da mulher resultará na diminuição dos parasitas que infestam a humanidade. É uma causa nobre e Raskolnikov começa a imaginar que ele próprio pertence a uma casta de "super-homens", os quais violam as regras sociais e cometem crimes que contribuem para diminuição das injustiças sociais. A mulher era razoavelmente rica e emprestava dinheiro aos necessitados, os quais deixavam jóias e objetos valiosos como garantia de pagamento. Muitos não conseguiam honrar os compromissos e, assim, a espertalhona vendia as peças por valores acima dos empréstimos. Raskolnikov era um desses pobres-coitados que haviam caído na armadilha da usurária.

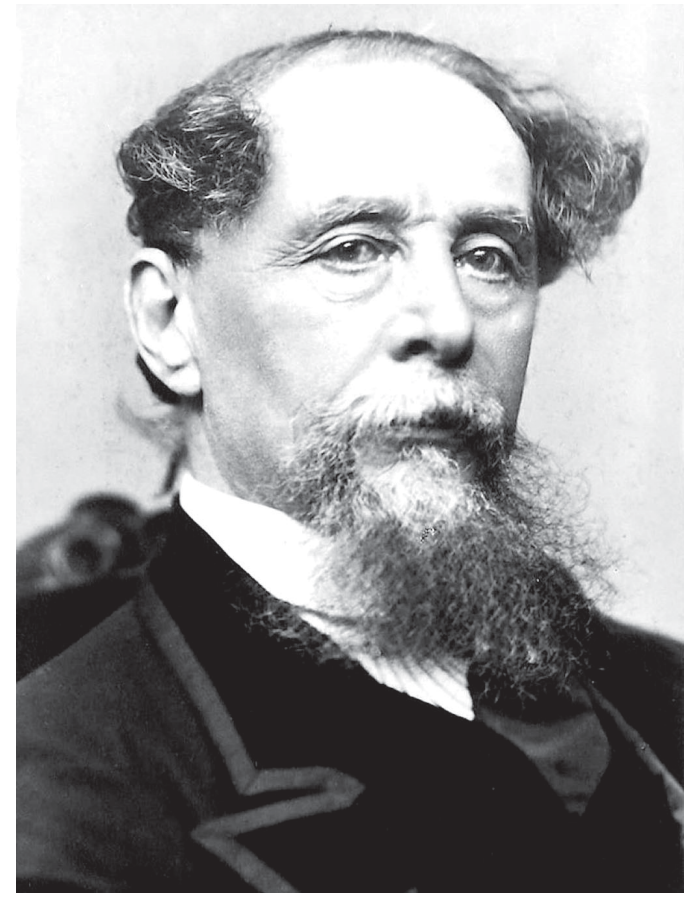

Figura 2

Charles Dickens (1812-70), escritor inglês cuja obra descreve o mundo miserável das crianças, as injustiças sociais e a ineficiência do antigo sistema judiciário. Seus personagens padecem de enfermidades mentais e ele consultava regularmente os periódicos científicos para dar substância aos seus enredos.

A longa ruminação que antecedeu ao crime induz Raskolnikov a um estado psicológico mórbido. Ele executa o duplo homicídio e se apodera de alguns valores da usurária, mas não aufere nenhum benefício devido a intensa perturbação mental. O estado evolui gradativamente para algo mais grave, 
pois Raskolnikov começa a ter delírios persecutórios, alucinações e é remoído por um intenso e inarredável remorso. Ao final, ele não suporta mais a sua miserável condição e confessa o crime a uma jovem prostituta. Dostoievsky fez uma análise sobre as razões que levam uma pessoa a cometer um crime, muitas vezes movidas pelo sentimento de onipotência. Ele tinha formação em matemática (era engenheiro civil) e usou suas habilidades para descrever o sofrimento humano numa perspectiva original e bastante realista. A linguagem clara e precisa é uma peculiaridade dos relatos científicos, mas também é o elemento que confere originalidade a certos clássicos da literatura.

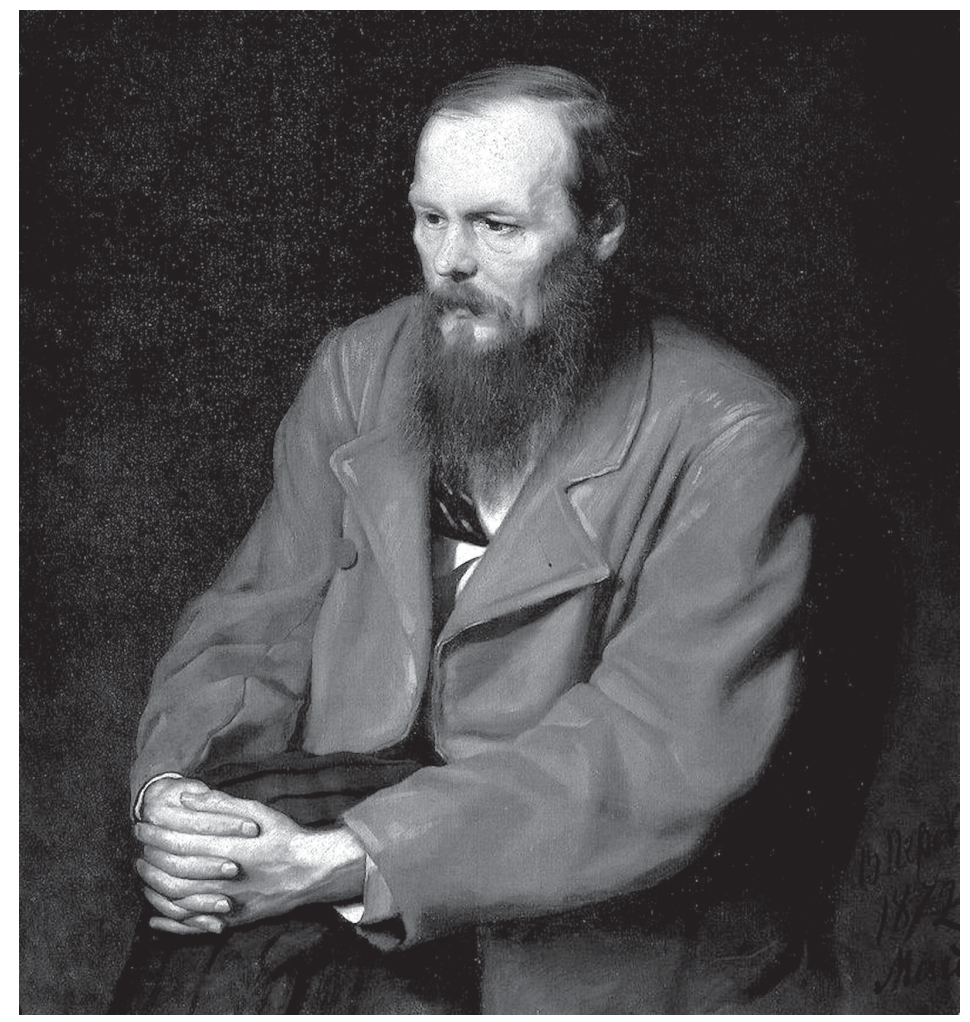

Figura 3

Fiodor Dostoievsky (1821-81), escritor russo que descreveu o sofrimento humano e graves enfermidades mentais. Na juventude, ele fora sentenciado à morte por suas atividades políticas, mas, no último momento, a sentença fora comutada para exílio na Sibéria (1849-54). Ele passou por grandes privações, teve convulsões epilépticas e sofreu intensa perturbação mental durante o exílio; a experiência foi recontada num livro (Recordações da casa dos mortos, 1860-61) e transparece no delineamento de seus personagens. 
O recurso ao conhecimento científico foi utilizado de modo ainda mais sofisticado por Thomas Mann (1875-1955), evidência inquestionável de quão produtivo é o consórcio entre a boa literatura e a boa ciência. Mann descreveu (Die betrogene, 1953) ${ }^{9}$ os efeitos da menopausa e de um tipo raro de câncer sobre a alma feminina; isso ocorreu quando ele beirava os oitenta anos e a obra foi escrita numa perspectiva de uma mulher jovem e atraente. Ao iniciar os preparativos para comemorar o aniversário de 50 anos, Rosalie von Tümmler, a bela viúva de um militar, começa a exibir os sintomas da síndrome climatérica, tais como ansiedade, dor de cabeça, irritação sem motivo aparente, palpitações, sensações térmicas estranhas (calores e arrepios) e depressão que se alongava por vários dias (DIETL, 2004). De modo geral e não obstante o desconforto, a viúva manifesta contentamento pela cessação dos fluxos menstruais, pois passa a sentir dona de seu próprio corpo. Rosalie adota uma atitude mais positiva em relação à vida e isto facilita o namoro com Ken, jovem de 24 anos e tutor de seu filho mais novo, mas a vida lhe reserva outra surpresa: ela repentinamente começa a ter novos fluxos menstruais e, então, começa a imaginar que o retorno do desconforto físico é o "preço" que ela deveria pagar pela volta da plena feminilidade; a aparência física melhora e todos cumprimentam Rosalie pelo seu rejuvenescimento. Ela tinha fortes restrições morais quanto ao namoro com o tutor de seu filho, mas a voz do coração fala mais alto e a bela viúva se deixa levar por uma intensa paixão. Numa noite, Rosalie é acometida de uma indisposição física e sofre uma intensa hemorragia. Ela é levada a um hospital e logo os exames indicam as causas daquilo que ela julgava ser um "milagre da natureza": um tumor ovariano, especificamente nos tecidos glanulares que produzem estrogênio, hormônio que controla as principais funções reprodutivas no corpo feminino. O tumor não podia ser inteiramente removido, pois havia se espalhado por outras partes do corpo, mas os médicos retiram o máximo possível para prolongar a vida da paciente. Desafortunadamente, Rosalie entra em coma e perde a vida sem grandes sofrimentos.

Autores consagrados do Brasil e do exterior realizaram descrições interessantes sobre enfermidades pouco conhecidas; a linguagem impecável explica o sucesso dessas obras, mas não devemos esquecer o valor da temática universal, i.e., as doenças e o sofrimento humano. Thomas Mann descrevera os infortúnios de frau von Tümmler talvez para realizar uma catarse de seus infortúnios. Aos 78 anos e dois anos antes de seu falecimento, ele havia sido diagnosticado com um carcinoma bronquial, o que o obrigou a se submeter a um tratamento com Frederick Rosenthal (1946), especialista em doenças pulmonares.

\footnotetext{
9 Thomas Mann. The black swan (comentários de N.P. Strauss). Berkeley: University of California,
} Press, 1990. 
Parece que a conversa entre os dois foi além do relacionamento médicopaciente, pois Mann lhe envia uma carta solicitando esclarecimentos sobre um tipo raro de câncer que atinge as mulheres. Rosenthal esclarece as dúvidas do romancista e anexa um paper sobre o assunto (The physiology and pathology of the ovaries in connection with symptoms during the menopause $)^{10}$. Basicamente, Mann fora alertado que o crescimento de tecidos granulares às vezes está relacionado com o aumento dos níveis de estrogênio na menopausa. O hiperestrogenismo reduz o desconforto da síndrome climáterica e as mulheres exibem melhoria no aspecto físico. Entretanto, tudo não passa de uma cruel ilusão, pois o "milagre da natureza" é resultante do crescimento desordenado de um câncer nos ovários. Die betrogene (1953) foi traduzido para o idioma inglês e recebeu o título The black swan ("cisne negro", gíria que significa trapaça ou logro) - caso o livro fosse traduzido para o nosso idioma, o título deveria ser algo como "A iludida". Também é interessante apontar que o sobrenome da bela viúva é derivado da palavra alemã tümmeln, que significa brincar ou abusar.

\section{Perturbações mentais}

Enfermidades mentais e os efeitos da expectativa da morte são temas áridos, mas o russo Leon Tolstoi (1828-1910) explorou bastante esta seara proibida. Num de seus romances (Anna Karenina, 1873-77), ele descreve o comportamento obsessivo e autodestrutivo, bem como os tics motores e verbais do príncipe Nikolai Levin. As anomalias comportamentais são facilmente identificáveis como sintomas da síndrome de Tourette, enfermidade mental descrita em 1885 por Gilles de la Tourette (1857-1904), neurologista francês. $\mathrm{O}$ escritor era bastante meticuloso e despendia um bom tempo com seus diários, um para registrar o dia-a-dia, outro para descrever suas impressões logo ao despertar do sono. Ele corretamente deduzira que o sono é um estágio da consciência, envolvendo um modo próprio de funcionamento do cérebro. O seu interesse por temas correlatos o levou a descrever sobre a "síndrome do cérebro dividido", distúrbio resultante de um acidente vascular cerebral; uma descrição bastante realista do distúrbio sofrido pelo príncipe Nicholas Bolkonski, personagem de Guerra e Paz (1865-69), revela o grau de acuracidade de Tolstoi sobre temas neurológicos e perturbações mentais (VEIN, 2007).

A evolução de uma doença e a expectativa de se deparar com a "verdade fundamental" foram examinados em A morte de Ivan Ilitch (1886) ${ }^{11}$,

\footnotetext{
${ }^{10}$ Letters of Thomas Mann 1889-1955. Berkeley: University of California Press, 1990.

${ }^{11}$ Leon Tolstoi. A morte de Ivan Ilitch - Senhores e servos. São Paulo: Martin Claret, 2005.
} 
conto que deveria ser leitura obrigatória nas escolas que formam os profissionais de saúde. Ao perceber os primeiros sintomas de uma misteriosa doença, Ivan Ilitch recorre aos médicos, mas não consegue se livrar dos incômodos; ele tinha 45 anos, ocupava uma elevada posição no Palácio de Justiça e vivia feliz com a esposa e os filhos. Certa ocasião, ele começa a sentir um estranho gosto na boca e dores ocasionais no lado esquerdo do ventre; os desconfortos aumentam de intensidade e Ivan Ilitch padece de tonturas, exaustão física e dores insuportáveis. Os médicos dizem isso e aquilo, ele recorre à homeopatia e até se descobre, envergonhado, ouvindo atentamente os relatos sobre os poderes miraculosos dos ícones. A enfermidade se agrava e ele concluiu que tudo aquilo era tolice e que seus dias estavam contados. Os efeitos são devastadores, pois Ivan Ilitch imaginava que estava numa fase ascendente da vida, mas a enfermidade lhe mostrou que ele estava descendo velozmente uma ladeira. A doença mobilizava seus sentidos, desde as pontadas nos rins ao odor fétido de seu hálito; o mau humor acompanhava as dores no corpo e ele só se acalmava na presença de Gerassim, rapazote forte e saudável que parecia não se incomodar com suas diatribes. Ivan Ilitch observava os braços fortes, a dentição perfeita e as maçãs salientes e coradas do rosto do fiel Gerassim, o que lhe despertava um choro inconsolável. "E se na verdade minha vida, minha vida consciente, não foi a que devia ter sido?" - indaga Ivan Ilitch a si mesmo. Os compêndios de lógica lhe ensinaram o silogismo de Kieseweter: "Caio é um homem, todos os homens são mortais, então Caio é mortal"; a mortalidade de Caio era natural e aplicável a todos os homens, mas Ivan Ilitch julgava-se pertencente a uma categoria especial de seres humanos. A doença o alertou para certos aspectos da vida. Seus amigos e familiares inicialmente se mostravam preocupados, mas ele logo percebeu que a sua doença representava um estorvo para todos.

Ivan Ilitch era um homem inteligente, racional e tinha um belo futuro pela frente, mas essas qualidades agravaram ainda mais a sua degradação mental. O relato de Tolstoi é realístico e perturbador. O enfrentamento da morte é um tema delicado que exige as mãos hábeis de um mestre, pois os relatos facilmente se tornam artificiais ou pouco convincentes. Interessantemente, os efeitos do luto e descrições realísticas sobre a morte podem ser encontráveis em algumas historietas infantis, como nas coletâneas dos irmãos Grimm (As aventuras do galo Chantecler e da galinha Partlet, 1812), Fiodor Dostoievsky ( $A$ árvore de Natal na casa de Cristo, 1848) e H.C. Andersen (A pequena vendedora de fósforos, 1874).

Dostoievsky e Tolstói são bastante estimados entre os especialistas que lidam com enfermidades mentais, mas carinho especial é direcionado a outro russo, Anton P. Tchekhov (1860-1904). Ele tinha formação em medicina e misturava o exercício profissional com literatura; uma frase revela como ele realizava isso: "A medicina é a minha esposa, a literatura é minha amante. 
Quando eu me canso de uma delas, passo a noite com a outra" (ver SCHWARTZ, 2004; IGIC, 2005). O conto La cigale (1892) descreve o relacionamento de uma jovem bonita e fútil com o esposo, um dedicado médico que vivia num mundo à parte. $\mathrm{O}$ conto é interessante, pois revela o conflito familiar que advém do idealismo e abnegação dos médicos. Olga Ivanovna tinha vários amigos no mundo das artes e vivia mergulhada em sonhos, enquanto que Dimov tinha hábitos caseiros e se dedicava integralmente aos seus pacientes; ela se sente atraída pelos amigos fúteis e acaba traindo o marido. Tal como o próprio Tchekhov, a abnegação do Dr. Oska Dimov resulta em graves moléstias infecciosas e ele morre muito jovem. Olga se dá conta de que perdera a convivência com uma pessoa nobre e bastante especial, remoendo-se em arrependimentos.

Tchekhov teve vida curta (falecera aos 44 anos, vítima de tuberculose pulmonar), mas deixou uma obra literária marcante e rica de significado psicológico. Seus contos e peças literárias contêm muitas observações sobre perturbações do sono, alcoolismo, epidemias e as peculiaridades da vida de um médico; ele tinha vários pacientes, mas muitos não tinham condições de remunerálo ou lhe pagavam apenas três ou quatro rublos a cada visita ${ }^{12}$. Movido por seus ideais, ele despendeu enorme esforço para visitar uma colônia penal na Ilha Sakhalina, distante $8.000 \mathrm{~km}$ da Sibéria e onde se abrigavam cerca de $10 \mathrm{mil}$ prisioneiros. Eles viviam em condições degradantes e padeciam do frio, máalimentação e castigos físicos violentos, os quais agravavam ainda mais suas misérias. Tchekhov descreveu as taxas de mortalidade e as condições degradantes da colônia penal e submeteu o relatório à Universidade de Moscou, para obtenção do título de doutor; o reitor recusou, alegando que o relatório era excessivamente "sociológico" (SCHWARTZ, 2004). O argumento talvez estivesse correto e, caso positivo, a característica seria uma qualidade, não defeito. Os três meses despendidos na Ilha Sakhalina agravaram a tuberculose de Tchekhov e o relatório antecedeu as descrições sobre os terríveis gulags mantidos pelo Czar Nicolau II e, posteriormente, pelos comunistas que se instalaram no poder (1917).

Tchekhov exercia a medicina em condições difíceis, mas não recusava atendimento aos pobres que o procuravam; ele reconheceu que a sua obra literária foi influenciada pelo contato direto com seus pacientes. Num de seus contos (O monge negro, 1894) $)^{13}$, ele descreve os surtos de megalomania e alucinações exibidas por Kovrin, um filósofo erudito. A gênese da perturbação é bem descrita, pois Kovrin inicialmente se depara com um misterioso monge, informando-o que ele era um gênio e que fora eleito por Deus para uma importante missão; esse tipo de soberba é o alimento do messianismo.

${ }^{12}$ Letters of Anton Chekhov to his family and friends. Nova York: McMillan Co., 1920.

${ }^{13}$ A.P. Tchekhov. O monge negro. Rio de Janeiro: Editora Rocco Ltda. 1987. 
Ele começa a dialogar com o misterioso personagem, mas começa a ter dúvidas sobre a sua real existência - "pense o que quiser. Eu existo na sua imaginação e como a sua imaginação é parte da natureza, devo existir na natureza", responde inteligentemente o monge. Os familiares se inquietam com as esquisitices de Kovrin e forçam-no a se livrar de sua "missão divina". O tratamento médico é bem sucedido, pois o monge desaparece de sua vida, mas ele gradativamente começa a se entediar com a vida, torna-se cruel e displicente no trato com as pessoas. No leito de morte as alucinações retornam e, diante da nova aparição do monge negro, Kovrin morre tranquilamente e com um sorriso de felicidade.

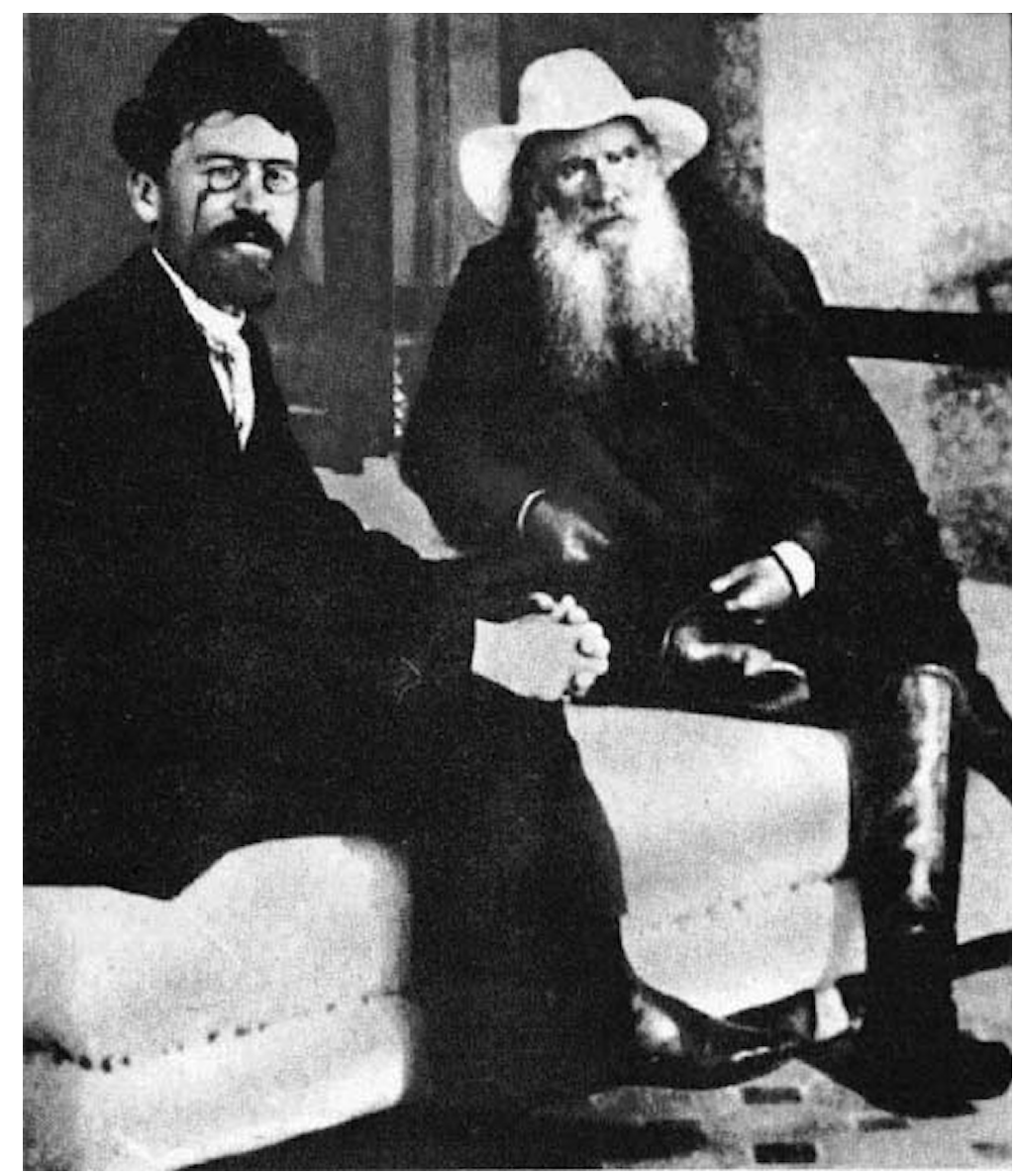

Figura 4

Anton P. Tchekhov (1860-1904) e Leon Tolstoi (1828-1910, à direita), escritores russos que descreveram distúrbios do sono, a evolução das enfermidades e a perturbação mental diante da expectativa de morte. 
O tratamento dispensado aos doentes mentais é severamente criticado em Enfermaria $n^{o} 6(1892)^{14}$, conto que descreve o dia-a-dia de um hospital e o tratamento dispensado aos pacientes psiquiátricos. Os pobres coitados eram mantidos como se fossem prisioneiros e os "procedimentos terapêuticos" eram conduzidos por Nikita, mistura de carcereiro e enfermeiro. Os espancamentos eram rotineiros e as autoridades faziam vistas grossas aos exageros de Nikita, pois acreditava que os castigos físicos "purificavam a alma" e contribuíam para a eficácia do tratamento. Num determinado momento, o Dr. Andrei Razin assume a direção da Enfermaria 6, mas é igualmente indiferente ao sofrimento dos pacientes - ele acreditava que a paz e a felicidade é um estado emocional que reside no interior das pessoas, independentemente das tragédias que ocorrem externamente. A confortável filosofia do Dr. Razin é repentinamente alterada, pois as pessoas começam a suspeitar que ele próprio estava perdendo a sanidade e, conseqüentemente, é internado na Enfermaria 6. Os castigos implacáveis de Nikita fazem-no ver que a paz e a felicidade são inatingíveis naquelas circunstâncias, mas a conclusão chega tarde demais. Os espancamentos ocasionam uma hemorragia cerebral e dão fim à vida de Razin; ele sentiu na própria pele o "valor terapêutico" dos castigos físicos, mas levou para o túmulo suas conclusões.

Desalento e tristeza são características marcantes da obra de Tchekhov, mas seus contos também descrevem fenômenos psicopatológicos com grande precisão. Em Varka (1888), o escritor descreve o trabalho servil e os efeitos da privação de sono numa menina adolescente. Com efeito, Varka fora designada a cuidar de um bebê e auxiliar nos trabalhos domésticos. De dia, ela limpava, lavava roupas, coletava lenha e acendia o fogo; de noite, ela embalava o bebê, filho de um sapateiro. O pai de Varka morrera e ela estava desamparada no mundo, só lhe restando a brutal servidão. Ela vivia num quarto escuro e pouco arejado, o bebê chorava quase que ininterruptamente e a menina não conseguia tempo para dormir sossegadamente; o sapateiro trabalhava no quarto ao lado, de onde vinham os odores nauseabundos do couro e das tintas dos sapatos, os quais sabidamente causam mal-estar ou dependência física. $\mathrm{O}$ choro ininterrupto do bebê impedia o sono de Varka e de vez em quando vinha o sapateiro ou sua mulher para xingar ou puxar suas orelhas; suas pálpebras pesavam como chumbo, mas o bebê não deixava a menina dormir. Ela tinha cochilos diurnos, mas era despertada aos gritos: "Varka!, traga mais lenha" ou "Varka!, encha o samovar". O trabalho físico extenuante, os odores do quarto fechado e a privação de sono promoveram intensa perturbação mental, pois a desafortunada menina começou a perceber nuvens escuras que se misturavam às visões do falecido pai. As alucinações ganham intensidade e, repentinamente, ao ouvir o choro forte do bebê, Varka consegue identificar o inimigo que a atormenta.

${ }^{14}$ A.P. Tchekhov. Ward no. 6 and other stories. Nova York: Barnes \& Noble Classics, 2003. 
Pensamentos estranhos emergem em sua mente e Varka passa por uma terrível transformação:

Uma idéia luminosa passa-lhe no cérebro pesado. Levanta-se vagarosamente do escabelo em que está sentada, com um claro sorriso no rosto embrutecido, e dá alguns passos. A idéia de libertar-se daquele que a impede de viver! Precisa matá-lo, e depois dormir, dormir, dormir... Sorrindo, rindo, e piscando os olhos, curva-se sobre o menino: e sufoca-o. Depois estende-se rapidamente no chão, sorrindo de alegria ao pensamento de que finalmente irá dormir. E adormece logo. Varka dorme um sono profundo e pesado como a morte (p. 175) ${ }^{15}$.

O que fazer com Varka? Ela fora privada de uma infância e necessitava de coisas elementares: apenas um pouco de ar puro e uma boa noite de sono. Assassinatos de bebês geralmente resultam em manchetes de jornais e as notícias são encontráveis nas páginas policiais. O que importa é o modus operandi e o resultado final da ação, mas por trás dessas tragédias existem as enfermidades mentais e o trágico enredo da vida real. Dr. Tchekhov realizou uma anamnese explicativa acerca da morbidez mental de Varka, mas deixou ao leitor a espinhosa tarefa de discernir o grau de culpabilidade da menina. Parece que ele queria dizer que essas tragédias devem ser examinadas numa perspectiva mais ampla, o que é condizente com as modernas práticas forenses e políticas que definem os direitos das crianças e dos adolescentes.

\section{Fanatismo, rebeliões e momentos históricos}

Alguns escritores tinham apreço pelo conhecimento científico, outros tinham formação condizente e usavam as habilidades para a renovação do estilo literário. O melhor exemplo brasileiro é a obra de Euclydes da Cunha (Os sertões: campanha de Canudos, 1902), a qual descreve o messianismo que prosperava nos grotões do Brasil. Falar com os espíritos, os transes mediúnicos ou antever os desígnios de Deus pode dar origem a sucessos cinematográficos, mas os manuais de psicopatologia explicam detalhadamente essas esquisitices. A obra descreve aspectos geomorfológicos, lança hipóteses interessantes sobre as causas da desertificação das caatingas e o leitor deve se munir de um bom dicionário para entender o complicado palavreado de seu autor.

${ }_{15}^{15}$ A.P. Tchekhov. Contos. Rio de Janeiro: W.M. Jackson Inc., 1953. 
Euclydes descreve o ambiente físico e as duas estações do ano (a da seca e a das chuvas, predominando a primeira), mas é inovador quando associa as adversidades ambientais às taras sociais: misticismo, religiosidade mórbida e loucura, os quais se somam ao debilitamento físico da população. A relação do homem com o meio ambiente é o ponto fundamental da moderna consciência ecológica, mas o assunto foi bem examinado no alvorecer do século passado.

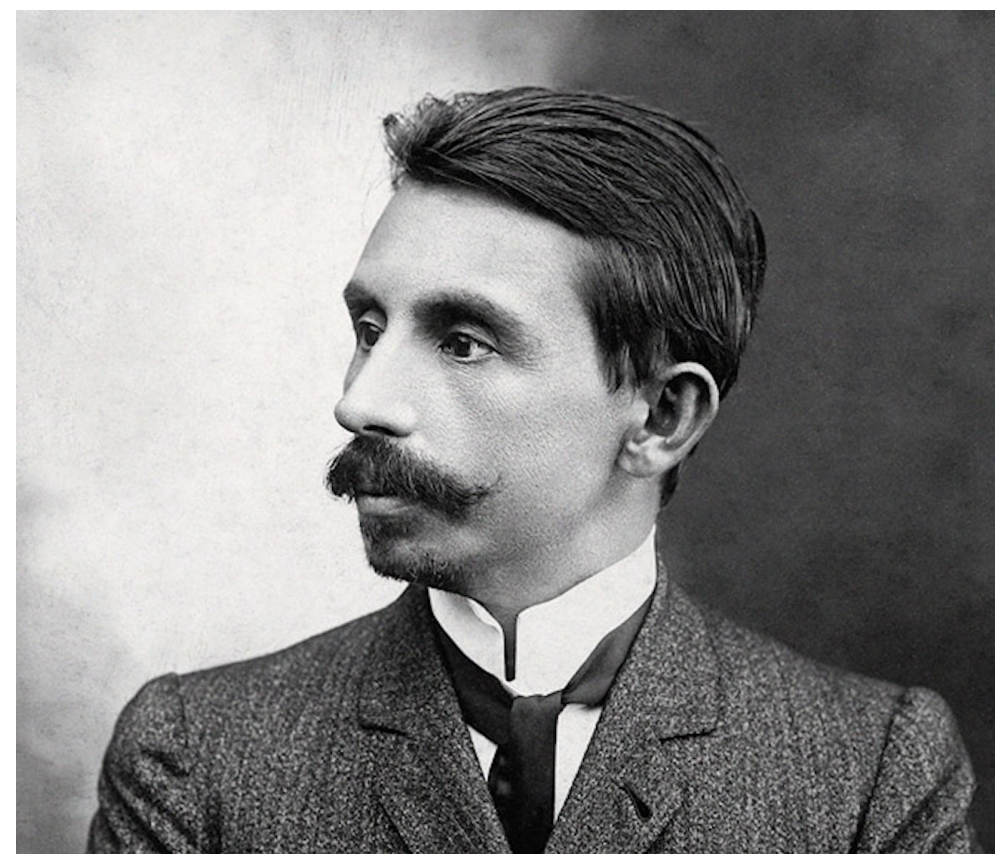

Figura 5

Euclydes da Cunha (1866-1909), engenheiro positivista cuja obra seminal (Os sertões: campanha de Canudos, 1902) descreve os efeitos sociais das enfermidades mentais e a gênese do fanatismo religioso.

A mestiçagem não é algo bem visto na obra de Euclydes da Cunha, pois geralmente o cruzamento das raças promove os "estigmas" da raça inferior "a mestiçagem extremada é um retrocesso". Ele era um apóstolo do higienismo, embora fosse engenheiro, não médico. O personagem central de sua obra é Antonio Maciel, o "conselheiro". Ele era um mestiço enfermiço e a sua situação se agravou com os reveses da vida. Com efeito, a sua família era composta por "homens ágeis, válidos e inteligentes", mas muitos familiares perderam a vida nas lutas sangrentas travadas pela família Maciel com os Araújos, inimigos de longa data. Com a morte do pai, Antonio Maciel fica encarregado da guarda das três irmãs solteiras e só se casa após o matrimônio destas. 
Outra tragédia: após o seu casamento, a esposa é raptada por um policial. O episódio lhe causa profunda vergonha, ele abandona a vida sedentária e busca refúgio na solidão das caatingas. A morte dos familiares, a responsabilidade pela guarda das irmãs e o adultério da mulher disparam "taras latentes": Antonio Maciel desaparece de cena e surge o Conselheiro.

Euclydes descreve que o Conselheiro tinha certas manias, como as idéias acerca do fim do milênio (pregava aos fiéis que o mundo sucumbiria à ira divina no ano 2000) e o modo recatado como se dirigia às mulheres; ele conversava de costas com as beatas, mesmo em relação às velhas feiíssimas que "amansavam sátiros". O aspecto físico e a conduta do Conselheiro causavam forte impressão:

[...] E surgia na Bahia o anacoreta sombrio, cabelos crescidos até aos ombros, barba inculta e longa; face escaveirada; olhar fulgurante; monstruoso, dentro de um hábito azul de brim americano; abordoado ao clássico, em que apóia o passo tardo dos peregrinos... Tornouse logo alguma coisa de fantástico ou mal-assombrado para aquelas gentes simples. Ao abeirar-se das rancharias dos tropeiros aquele velho singular, de pouco mais de trinta anos, fazia que cessassem os improvisos e as violas festivas. Era natural. Ele surdia - esquálido e macerado - dentro do hábito escorrido, sem relevos, mudo, como uma sombra, das chapadas povoadas de duendes... Passava, buscando outros lugares, deixando absortos aos matutos supersticiosos. Dominava-os por fim, sem querer (p. 178) ${ }^{16}$.

Euclydes da Cunha é arrojado quando traz à tona outra novidade: momentos importantes da nossa história ou o surgimento de lideranças podem ser frutos de perturbações mentais. Algo parecido também emerge nos relatos de Ambrosio Schüpp (1840-1914), padre jesuíta que descreveu os tresloucados projetos de Jacobina Maurer, uma jovem esposa que tinha êxtases mediúnicos e que liderara a pouca conhecida revolta dos muckers. Ela e o conselheiro sofriam de graves perturbações mentais e lideraram rebeliões de fanáticos no Morro do Ferrabráz (Rio Grande do Sul) e em Canudos (sertão da Bahia). Em ambos os casos, a intervenção governamental foi desastrosa e resultou num número elevado de mortes.

${ }^{16}$ Euclydes da Cunha. Os sertões. Rio de Janeiro: Francisco Alves, 1997 (39 edição). 
O fanatismo e o conflito dos muckers com a ordem social estabelecida (1872-74) antecederam a revolta de Canudos (1896-97). Os personagens principais acreditavam ser reencarnação do Cristo e exibiam atitudes soberbas, mas uma mulher jovem assumindo esse papel é algo inusitado. Padre Schüpp não tinha a pretensão de explicar tantas coisas como Euclydes da Cunha, mas seus relatos sobre a evolução da perturbação mental sofrida por Jacobina Maurer são mais interessantes para uma análise psicopatológica. Ele era loyolista genuíno, enquanto Euclydes da Cunha era um engenheiro, positivista e simpatizante do higienismo; a obra do Padre Schüpp foi inicialmente publicada na Alemanha (1900) e no ano seguinte foi traduzida para o nosso idioma. Diante da incredulidade dos leitores, Padre Schüpp publicou uma nota no jornal da comunidade alemã de São Leopoldo (Deutsches Volksblatt, 1900), ressaltando a autenticidade da história e, ao mesmo tempo, incitando os sobreviventes da rebelião a apontarem algo que não estivesse de acordo com os fatos. Coisas de um loyolista.

A rebelião e as extravagâncias dos muckers (santarrão ou falso beato, no idioma alemão) tiveram início quando João Jorge Maurer, marido de Jacobina, começou a "ouvir" vozes misteriosas. O moço é descrito como de estatura mediana e de rosto cheio, adornado com uma barba cerrada de cor castanha; ele era de índole pacífica e as linhas de seu rosto não denunciavam inteligência acima do comum ou energia acima do vulgar, assim informou Padre Schüpp. Certo dia, Maurer estava trabalhando na roça e, após muitas machadadas para limpar o terreno, ele resolveu interromper a faina para o merecido o repouso. Uma "voz" misteriosa chega-lhe aos ouvidos: "João Jorge, que está aí a mourejar? Lança fora esse machado, e trata de seguir a sua vocação: tu nasceste para médico". Como geralmente ocorre em relação a tais fenômenos, Maurer concluiu que a "voz" tinha algo de divino; movido por objetivos terrenos, ele se torna wunderdoktor (curandeiro ou charlatão, no idioma alemão).

Os pacientes começam a bater às portas, vindos de São Leopoldo, Porto Alegre e até Pelotas; eles eram pobres, ignorantes ou vinham desenganados por médicos verdadeiros. Maurer começa a ganhar fama de milagreiro, mas a fama era facilmente explicada: existiam poucos médicos formados e os pacientes tinham que buscar o atendimento adequado nos grandes centros urbanos. As viagens eram realizadas em carroções ou no lombo de cavalos e os honorários médicos consumiam os recursos das famílias. Tal como ainda ocorre nos grotões do Brasil, tudo concorria para o sucesso do charlatão. Alguns pacientes ficavam "curados" de suas enfermidades, mas, por falta de dinheiro para a viagem de retorno ou porque desejavam saciar a fome espiritual, permaneciam na região e engrossavam a lista de adeptos do wunderdoktor. Eles construíram um templo e uma espécie de enfermaria e dão início aos rituais religiosos, proibindo aos fiéis de freqüentarem as missas na igreja local. 


\section{HuMANANAs}

João Jorge era muito confiante em si mesmo e transmitia a sua confiança aos pacientes. Ele tinha beberagens para todos os males, ouvia atentamente os relatos dos pacientes e impunha a estes que se instalassem na vizinhança para o prosseguimento do tratamento. O simples repouso e a mudança na dura rotina diária eram suficientes para a promoção da "cura", mas os matutos atribuíam o bem-estar às habilidades do charlatão. Jacobina logo começa a auxiliar o marido, pois ela tinha capacidade paranormal de efetuar diagnósticos das enfermidades. Ela vinha de uma família de anabatistas (seita protestante que impõe um segundo batismo, quando o indivíduo adulto ganha a razão). Aos oito anos de idade, ela já exibia comportamento estranho, tinha convulsões e uma acentuada tendência ao misticismo. Jacobina também interpretava de modo extravagante certos trechos da Bíblia e suas "visões proféticas" tornam-se cada vez mais freqüentes com o gradativo sucesso de João Jorge. As mensagens eram confusas e estapafúrdias, mas os colonos ficavam ainda mais convencidos que Jacobina era instruída por uma sabedoria superior - as mensagens vinham do outro mundo e, portanto, era natural que fossem incompreensíveis.

Marido e mulher viviam numa loucura conjugal, um alimentando a insanidade do outro (follie à famille), mas João Jorge começou a perder prestígio diante dos sonhos proféticos e das estranhas visões de Jacobina. Gradativamente, ela se torna líder dos muckers, ditando normas ao esposo e aos colonos. Em torno do casal se reúne um grande número de devotos; eles constroem uma fortificação, estocam pólvora, armas e munições para se defenderem das autoridades e demais moradores da região. Num determinado momento, Jacobina declara que João Jorge não estava mais à altura de suas responsabilidades, de modo que ela troca o marido pelo amante, transferindo a esposa deste para João Jorge. O jornal da comunidade alemã (Deutsche Zeitung) publica uma matéria esclarecendo o perigo que os muckers representavam para a comunidade:

A seita era imoral, pois pregava o comunismo,
estendendo-o até ao matrimônio; que era perigo-
sa para a sociedade, porque ali se ensinava que
aquele que não pertencia à seita, devia ser conta-
do entre os mortos, e que o Mucker que matasse
os adversários, fosse qual fosse o número destes,
não matava senão animais; que a seita consti-
tuía uma ameaça e um perigo para o estado, pois
ali se conculcavam as leis do país, e se prepa-
ra o caminho à revolução; que, se o governo
não livrasse a sociedade daqueles monstros, 
não seria para admirar se os colonos alemães recorressem ao linchamento, resultando daí mortes e assassinatos (p. 147) ${ }^{17}$.

Os moradores viviam amedrontados pelo crescente fanatismo dos $m u$ ckers e só desejavam sossego. A Igreja Católica também desejava uma ação mais efetiva das autoridades civis, de modo que o movimento acabou sendo exterminado em 2 de Agosto/1874. O templo dos muckers foi incendiado e eles morreram cantando hinos em louvor ao Espírito Santo, pois imaginavam que a imolação de seus corpos era a garantia de vida eterna no Céu. Jacobina busca refúgio longe da turba e ordena a morte da filha recém-nascida, Leidard, antes de receber os golpes fatais de baioneta desferidos pelos soldados. O amante Rodolfo morre da mesma forma, ao lado do Cristo reencarnado no corpo de mulher.

A gênese do movimento messiânico foi examinada por M.B. Lourenço Filho (1897-1970), influente educador e psicólogo brasileiro que descreveu os traços de personalidade do Padre Cícero, bem como as histórias que lhe deram fama de milagreiro. O seu livro inicial (Juazeiro do Padre Cícero, 1926) foi premiado pela Academia Brasileira de Letras e, tal como os relatos de Euclydes da Cunha e do Padre Schüpp, mistura as peculiaridades de um relatório técnico com os elementos de uma genuína obra literária. Lourenço Filho descreveu as circunstâncias que deram origem à devoção imerecida do Padre Cícero: a hóstia que saíra da boca da beata Maria de Araújo encharcada de sangue e a história do boi que, através de uma estranha expressão e mugido inusitado, repudiara o delito de seu tratador. Foi algo de pouca significância: o tratador fora designado a cuidar do boi do Padre Cícero, mas a seca o forçou a roubar capim tenro na roça de um vizinho, o que provocou mugidos de desagrado no bovino. O primeiro e mais importante "milagre" ocorreu em 11 de Junho/ 1890, numa capelinha de N.S. das Dores. Ao receber a hóstia das mãos do Padre Cícero, Maria Beata caíra no chão, movida por uma violenta crise dos nervos. Os fiéis perceberam que da sua boca saía um fiozinho de sangue e a hóstia havia se tornada rubra com o "sangue do Cristo".

O sangue do Redentor saíra das gengivas maltratadas de Maria Beata, mulher "caquética" e de personalidade "cacodemoníaca". As convulsões e os sangramentos bucais explicam facilmente a coloração da hóstia, mas o sofrimento de Cristo está mais de acordo com o fanatismo e susceptibilidade mística das pessoas que cercavam o padre milagreiro. Os mugidos e a "expressão de desagrado" do bovino também ultrapassam ao fantástico e ao implausível,

${ }^{17}$ Padre Ambrosio Schüpp, S.J.. Os muckers: episódio histórico ocorrido nas colônias alemãs do Rio Grande do Sul. Brasília: Edições do Senado Federal, 2004. Ver também: L. Petry. O episódio do Ferrabraz. São Leopoldo: Casa Editora Rotermund S.A., 1966. 
mas a propensão ao fanatismo levou os moradores a julgarem que eram manifestações autênticas do Espírito Santo. Os fiéis adornavam a manjedoura e enfeitavam com lacinhos e utilizavam os produtos do animal (fragmentos dos chifres e cascos ou urina) para fins medicinais, pois eles acreditavam que curavam quebranto, espinhela caída, bouba legítima e sapiranga. O culto ao ruminante era tão exagerado, de modo que o tratador e seus comparsas foram para cadeia e o principal aliado do Padre Cícero, o esperto Dr. Floro Bartolomeu, ordena a imolação do boi em praça pública. Foi uma comoção.

\section{Os epônimos: de Lázaro a Stendhal}

O que são epônimos? São designações de fenômenos naturais, acidentes geográficos ou doenças a partir do nome de seu descobridor ou personagens mitológicos. Um epônimo bastante conhecido diz respeito à Aquiles, herói da mitologia grega, filho de Pelen e da ninfa Tétis. Com o intuito de tornar o filho imortal e invulnerável aos ferimentos das batalhas, a mãe segura o bebê por um de seus calcanhares e gentilmente o banha nas águas do Rio Estige. Alertado pelos deuses sobre esta parte vulnerável do corpo, Paris de Tróia, em vingança à morte de seu irmão, desfere uma flecha envenenada no calcanhar de Aquiles, dando fim à vida do herói troiano. "Calcanhar de Aquiles" é uma expressão de grande significado e é utilizada para designar o ponto fraco de uma pessoa, seja intelectual, emocional ou moral. Outra curiosidade é "pomo de Adão" (tecido cartilaginoso na parte frontal do pescoço de homens, devido ao "engasgo" que Adão sofrera quando provara o fruto proibido no Paraíso). As duas expressões são perfeitamente funcionais na comunicação cotidiana, mas poucas pessoas conhecem suas origens.

Essas preciosidade etimológicas revelam anacronismo, mas o vocabulário científico é um baú rico em coisas parecidas. Com efeito, fenômenos inusitados ou a descoberta do mecanismo causal de uma enfermidade geralmente são designados tomando como empréstimo o nome do responsável pela façanha, como "doença de Hansen" (hanseníase), enfermidade que aflige a humanidade desde os tempos bíblicos. O agente causador (o bacilo Mycobacterium leprae) foi descoberto em 1873 por Gerhard H.A. Hansen (1841-1912), médico norueguês. A enfermidade também era conhecida como lepra ou "mal de Lázaro" - os pacientes eram chamados de "lazarentos" e eram atendidos em "leprosários" ou "lazaretos". O epônimo é uma menção à Lázaro, mendigo que carregava no corpo várias úlceras e chagas e que fora merecedor da compaixão de Jesus (Lc 16: 19-31). A alusão ao mendigo que padecera da doença e ao Dr. Hansen ("mal de Lázaro" e "doença de Hansen") revela duas coisas: designações eponímicas podem mudar com o tempo e induzem a erros, pois não informam a relação do "homenageado" com o fenômeno em questão. 
A análise etimológica da palavra sífilis revela outras curiosidades e um epônimo oculto, com significado literário. Trata-se de uma doença sexualmente transmissível cujo agente causador é o espiroqueta Treponema pallidum. Ela era conhecida na antiguidade por vários nomes, como "mal de Santa Eufêmia", "mal de São Jó" ou "mal de São Névio", personagens mencionados na Bíblia e que supostamente padeceram da enfermidade. É interessante apontar que Syphilus é o personagem central do poema Syphilis, sive Morbus Gallicus (1530), de Girolamo Fracastoro (1478-1553), médico, astrônomo e poeta italiano. Syphilus era um pastor que incitara o povo de Ofisa a abandonar o culto ao deus Sol e que, em razão disso, Apolo o castigara infringindo-lhe chagas pelo corpo. A doença ficou associada ao pastor e o "mal de Syphilus" e "mal de Lázaro" (lepra) foram considerados a mesma enfermidade. Fracastoro tinha notável capacidade observacional, pois o seu livro De contagione et contagiosis morbis (1564) chegara a antecipar algumas idéias de Louis Pasteur sobre o papel dos germes e micro-organismos na propagação de doenças.

Os relatos de Stendhal (1783-1842, pseudônimo do romancista francês Marie-Henri Beyle) serviram de inspiração para a criação de um epônimo: síndrome de Stendhal. A terminologia foi sugerida por Graziella Maghirini (1992), médica-psiquiatra italiana que se baseara nas sensações de déjà-vu e surtos de ansiedades que o romancista exibira no momento de sua visita aos museus de artes em Florença - Stendhal descreveu suas perturbações mentais no livro Rome, Naples et Florence em 1817 (1817). Algo parecido ocorreu com Sigmund Freud (1936), pois ele relatou as perturbações mnemônicas que sofrera durante uma visita às ruínas de Acrópoles (Grécia). Uma análise feita por Amâncio (2005) revelou que Dostoievsky também exibira os sinais da síndrome de Stendhal quando contemplava a pintura $O$ Cristo morto, obra de Hans Holbein (1497-1543), e repassara suas perturbações ao príncipe Mischkin, personagem central do romance $O$ idiota (1866).

Pessoas acometidas da síndrome de Stendhal exibem surtos de ansiedade, alterações no ritmo dos batimentos cardíacos, confusão mental e até alucinações quando contemplam obras-prima (i.e., pinturas, esculturas e obras arquitetônicas). Uma análise dos registros hospitalares de Florença (1977-86) revelou que alguns turistas recorriam aos serviços de saúde, pois exibiam certas perturbações mentais quando visitavam os museus da cidade (MAGHERINI, 1992). O distúrbio serviu de inspiração ao The Stendhal syndrome (1996), filme dirigido por Dario Argento, cineasta italiano e mestre do gênero bizarro. O filme explora os efeitos do distúrbio sobre o comportamento de uma policial (Asia Argento, filha do diretor); ao perseguir um serial killer, ela acaba caindo numa armadilha dentro de um museu. 


\section{HUMANAS}

Turistas que apreciam obras de arte e reverenciam artistas consagrados são mais susceptíveis à síndrome de Stendhal (SANFORD, 2004). O distúrbio também é conhecido como "síndrome de Florença" ou "mal de Dostoievsky" e tem muita semelhança com a "síndrome de Jerusalém". Da mesma forma que algumas perturbações mentais podem aflorar em pessoas que visitam museus ou ruínas históricas, algo parecido ocorre quando elas visitam lugares santos, como a cidade de Jerusalém, onde o fenômeno foi inicialmente investigado, Meca ou santuários dedicados à Virgem Maria (ver BAR-EL et al., 2000). O significado histórico e/ou a religiosidade intrínseca potencializam ou despertam perturbações mentais latentes, de modo que a pessoa pode ter ideações religiosas, como identificação com um personagem bíblico, sentimentos obsessivos sobre uma suposta missão na Terra ou, de forma mais branda, aumento do proselitismo e do fervor religioso.

\section{As coisas do Reverendo Dodgson}

As historietas infantis revelam o tratamento dispensado aos órfãos, idosos e deficientes físicos (ver GUERRA, 2009). Alguns personagens exibem anomalias comportamentais e, com efeito, inspiraram formulações de epônimos que designam enfermidades mentais. Os clássicos da literatura infantil são importantes para uma análise desse tipo, mas nada se equipara à obra de Lewis Carroll (pseudônimo de Charles Lutwidge Dodgson, 1832-98), matemático e clérigo de Christ College, a alma mater da Universidade de Oxford (ver CLARK, 1979; COHEN, 1995). As aventuras de Alice sempre despertaram as atenções de scholar respeitáveis e uma edição comemorativa veio acompanhada de comentários e notas explicativas de Martin Gardner, especialista em lógica e matemática ${ }^{18}$. Parece que Alice no País das Maravilhas (1865) seria um ensaio especulativo acerca do que ocorreria com uma pessoa, caso ela fosse sugada por um wormhole, estrutura hipotética que liga duas regiões distantes no espaço-tempo. As bizarrices de Carroll descrevem problemas matemáticos complexos, paradoxos e argumentos lógicos, mas sem sentido (ver FALK \& SAMUEL-COHN, 2001; MAGALHÃES, 2004).

Algumas idiossincrasias de Carroll foram localizadas em Através do espelho e o que Alice encontrou lá (1871). Com efeito, parece que o tema central surgiu de um problema funcional de escrita (letra "espelhada") - Carroll escrevia com a mão direita, mas parece que era canhoto por natureza (SCHOTT, 1999). O nome do personagem Humpty Dumpty parece ser uma onomatopéia que indica ritmo vocal acelerado; também foi sugerido que o nome do personagem Dodô sinaliza as dificuldades que o gago Carroll tinha em pronunciar o próprio sobrenome: "Do-Do-Dogson" (LARNER, 2004).

\footnotetext{
${ }^{18}$ Lewis Carroll. Alice - Edição comentada. Rio de Janeiro: Jorge Zahar, Editor, 2002.
} 
As aventuras de Alice descrevem distúrbios comportamentais pouco conhecidos nos dias de hoje, como a prosopagnosia (agnosia visual que impede as pessoas de reconhecerem rostos familiares) e senestesia (distúrbio neurocognitivo que provoca confusão no processamento de informações oriundas de diferentes órgãos sensoriais, como perceber cores ou sentir o sabor diante de um estímulo sonoro).
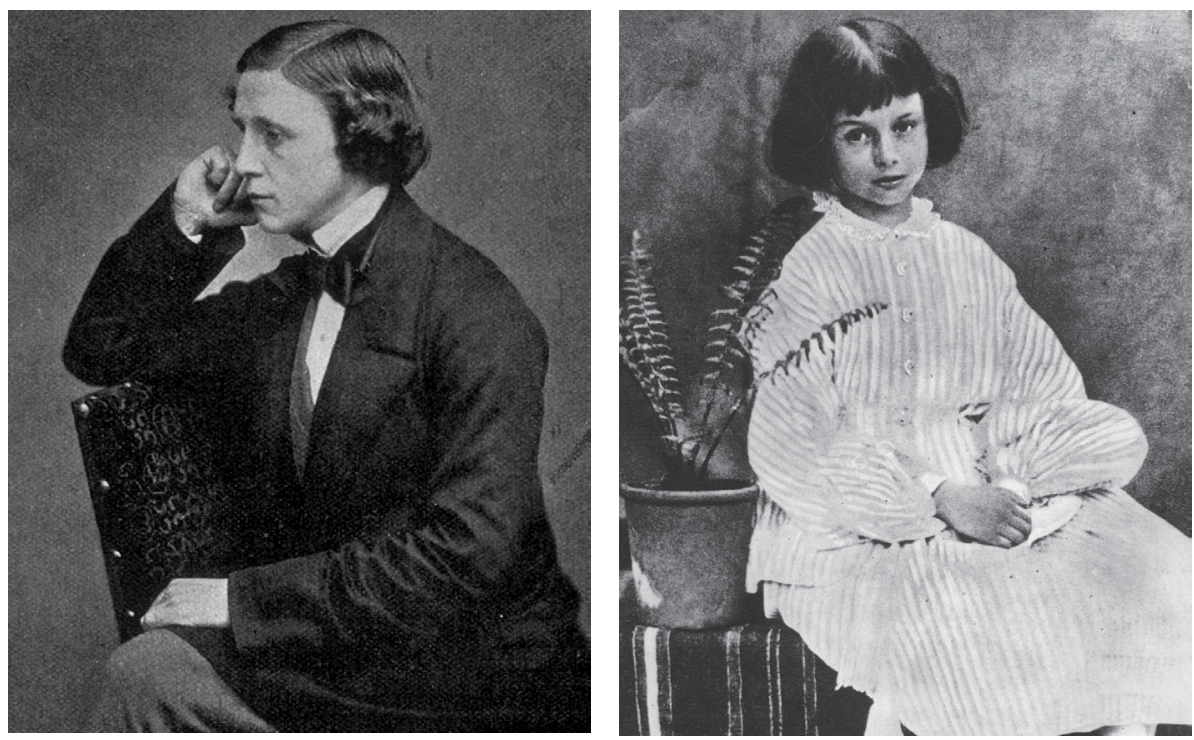

Figura 6

Lewis Carroll (1832-98) e Alice Lidell (falecida em 1934), filha do reitor do Oxford College. Carroll fora designado preceptor da menina e suas histórias tinham o propósito inicial de entretê-la durante os passeios de barco, mas elas descrevem enfermidades mentais pouco conhecidas e são recheadas de enigmas matemáticos.

As crianças se encantam com as estripulias de Alice, mas a obra de Carroll aborda temas complexos e críticas ao despotismo político e religioso. Tudo isso se encontra numa obra originalmente direcionada às crianças, o que é espantoso. Os enredos revelam uma atitude avançada em relação ao gênero feminino, pois a inteligente e auto-suficiente Alice não tem nenhum parentesco com Rapunzel ou Pele de Asno. Os leitores estavam acostumados com os moleques endiabrados de, por exemplo, Mark Twain (1835-1910) e José Lins do Rego (1901-57), mas a ousadia de Alice era diferente. Lewis Carroll é uma unanimidade: as crianças apreciam o nonsense de suas histórias e scholars respeitáveis recorrem à sua obra quando examinam fenômenos psicopatológicos pouco conhecidos. Alguns deles serão examinados a seguir. 
Síndrome de "Alice no País das Maravilhas". A personagem principal das histórias de Carroll exibe um tipo raro de perturbação perceptiva que envolve distorção do tamanho ou das formas de objetos, animais e pessoas. O fenômeno foi descrito por Caro W. Lippman (1886-1954) e logo foi relacionado às aventuras de Alice, mas a designação eponímica foi proposta pelo psiquiatra inglês John Todd (1914-87); isto explica porque a síndrome de Alice no País das Maravilhas também é conhecida como síndrome de Todd. As histórias mostram que Alice exibia macropsia e micropsia (percepção de objetos e pessoas com tamanho maior ou menor que o real), sensação de levitação, sentimentos de déjà-vu ou jamais-vu e perda da noção do tempo e espaço (LIPPMAN, 1952; TODD, 1955; RESTAK, 2006). A síndrome pode estar associada à epilepsia, consumo de drogas (lembremos que Alice ingere uma estranha bebida antes de iniciar suas "aventuras"), infecção viral ou é ocasionada por um tipo severo de enxaqueca que causa as perturbações visuais. Os biógrafos de Carroll relatam que ele sofria de terríveis enxaquecas, mas alguns especialistas argumentam que as perturbações talvez fossem resultantes de uma epilepsia no lobo temporal (RESTAK, 2006).

Alucinações lilliputianas. A obra de Jonathan Swift (1667-1745), escritor irlandês, também descreve um distúrbio parecido com a síndrome de Alice no País das Maravilhas. Com efeito, o personagem homônimo de As viagens de Gulliver (1726) exibiu perturbações visuais quando se encontrava em Lilliput, reino de criaturas diminutas, de onde veio a nova designação eponímica. Os pacientes relatam a percepção anormalmente miniaturizada de pessoas, animais e objetos, parados ou em movimento - os especialistas postulam que alucinação lilliputiana e síndrome de Alice no País das Maravilhas são nomes diferentes para o mesmo distúrbio. O quadro clínico está relacionado com um tipo raro de enxaqueca, uso de drogas psicoativas (LSD ou cocaína, por exemplo), lesões no tálamo ou mesencéfalo e doenças neurodegenerativas (BURNS et al., 2004; McCALLUM \& SMITH, 2005). Os pacientes geralmente têm consciência de que se trata de um distúrbio da percepção, mas alguns apreciam ou usam as alucinações lilliputianas como fonte de inspiração para a produção de pinturas artísticas (ATKINSON \& APPENZELLER, 1978; PODOLL \& ROBINSON, 1992 e 2001).

Doença do Chapeleiro Maluco. Também conhecida como eretismo, hipersensibilidade corporal ou instabilidade emocional ocasionada por intoxicação ou envenenamento. O epônimo foi inspirado no personagem homônimo de Alice no País das Maravilhas (1865). As ilustrações mostram o chapeleiro sempre ostentando uma cartola, mas ele é conhecido por suas frases desconcertantes ou aparentemente idênticas que comportam significados bem diferentes (e.g., "respiro quando durmo" e "durmo quando respiro" ou "aprecio o que tenho" e "tenho o que aprecio"). Cartolas e chapéus eram itens obrigatórios do vestuário masculino; 
o formato adequado era obtido com o uso de peles coelhos, as quais eram curtidas com mercúrio. Os artesãos padeciam de uma contaminação crônica e suas perturbações serviram de referência para a designação eponímica; os chapeleiros trabalhavam em ambiente fechado e a intoxicação com os vapores de nitrato de mercúrio dava origem a sérios distúrbios motores, alucinações visuais, problemas na fala e até psicose (O'CARROLL et al., 1995; LARNER, 2005; RESTAK, 2006). As expressões as mad as a hatter ("tão louco quanto um chapeleiro", alguém muito excêntrico ou fora do convencional) e hatter's shakes ("espasmos de chapeleiro") já eram conhecidas dos ingleses desde o início do século 19, mas Carroll tornou a doença dos chapeleiros conhecida no mundo inteiro.

Efeito Rainha Vermelha. Trata-se de um epônimo inspirado numa estranha personagem de Através do espelho e o que Alice encontrou lá (1871). Num determinado momento, a Rainha Vermelha segura a mão de Alice e envolve a menina numa intensa e desenfreada correria. Alice quase perde o fôlego, mas a rainha não solta a sua mão e incita: "Corra! Mais rápido! Mais rápido!” Após algum tempo nessa maluquice, a rainha cede aos apelos de Alice e permite que ela descanse debaixo de uma árvore. Espantada, a menina percebe que não saíra do lugar e permanecera durante todo o tempo próxima à árvore. Ela deixa transparecer o espanto, mas a rainha, ainda mais espantada com o espanto de Alice, lhe informa as peculiaridades do local: "Nesta terra você tem que correr o máximo que puder para continuar no mesmo lugar". A expressão "efeito Rainha Vermelha" (ou "Hipótese Rainha Vermelha") é utilizada para descrever a competição entre as espécies (Van VALEN, 1973; HOFFMAN, 1991) e a vida agitada dos homens de negócios (VOELPEL et al., 2005). A "luta pela sobrevivência" entre os animais e empresários é uma corrida incessante na qual os atores buscam extrair vantagens, mas mudanças sutis provocam adaptações entre os competidores e estas mudanças alimentam outras mudanças, de forma que todos devem "correr" o máximo possível para "permanecerem no mesmo lugar".

O "sorriso do gato de Cheshire". Uma das peculiaridades da obra do Reverendo Dodgson são os personagem, cada um mais estranho que o outro. O gato de Cheshire tem importância secundária, mas é muito lembrado por intelectuais e apreciadores do conto Alice no País das Maravilhas (1865). A expressão "sorriso de um gato de Cheshire" tem origem incerta, mas existem duas explicações. A primeira diz que um pintor do condado de Cheshire tivera a idéia de pintar as tabuletas das hospedarias com a imagem de um leão sorrindo, algo marcante e que pretendia sugerir o sentimento de segurança aos hóspedes. A explicação só tem sentido se esquecermos a ferocidade dos leões e levarmos em conta a semelhança entre as duas espécies de felinos. 
Outra explicação, talvez a mais plausível, informa que os queijos do condado eram feitos com formato de um gato, talvez representando o desejo que os ratos fossem mantidos distantes da iguaria; o queijo era consumido a partir da cauda do gato, de forma que ao final só restava a face sorridente do bichano.

As ilustrações originais de Sir John Tenniel (1820-1914) mostram o bichano sorrindo de modo estranho, fato que levou alguns pesquisadores a verem certa semelhança com o cenho exibido por pessoas que sofrem de fibromialgia (patologia muscular que provoca fortes dores). O gato de Cheshire também ficou conhecido pelo modo como desaparecia: às vezes devagarzinho, começando pela extremidade da cauda, ou repentinamente e só deixando visível a face e o sorriso enigmático. Diante desse inusitado fenômeno, Alice dizia: "Eu conheço gato sem sorriso, mas nunca vi na minha vida um sorriso sem gato". O epônimo síndrome do gato de Cheshire surgiu a partir das observações clínicas de E.G. Bywaters, reumatologista inglês. A nomenclatura deve ser examinada com cuidado, pois ela não se refere a uma doença ou algum fenômeno biológico, mas descreve as dificuldades que os médicos encontram para diagnosticar e tratar com segurança uma enfermidade cujos sintomas emergem gradativamente. Em tais circunstâncias, eles enfrentam o dilema: se agem rápido, o diagnóstico e os procedimentos terapêuticos podem ser inadequados, mas se esperam a manifestação de todos os sinais e sintomas, para o diagnóstico seguro, a perda de tempo pode agravar e/ou dificultar ainda mais o tratamento da doença (BYWATERS, 1968).

A metáfora do gato de Cheshire também é utilizada para designar o trabalho invisível de certas categorias profissionais, como a enfermagem que exibe ao público somente o "sorriso" do bichano, escondendo as demais partes de seu corpo (PROEHL, 1999). Os aparecimentos e sumiços gradativos do gato também servem de alegoria nas discussões sobre o que é um ser humano, pois alguns juristas consideram fetos (o corpo surgindo a partir do "sorriso") como seres humanos completos, da mesma forma que um morto ainda preserva o status de ser vivente, pois suas cartas, diários e testamentos ainda influenciam as ações de seus advogados e familiares - a pessoa morreu, mas o "sorriso" do bichano ainda permanece no mundo real (NAFFINE, 2003). O enigmático personagem de Carroll também serviu de inspiração para a formulação de conceitos relacionados às propriedades evanescentes de partículas elementares: princípio gato de Cheshire (ou fenômeno gato de Cheshire). Nos limites da cosmologia, as peculiaridades da criatura serviram até para explicar o "sumiço" de Deus: Operationally, God is beginning to resemble not a ruler but the last fading smile of a cosmic Cheshire (Julian Huxley, 1887-1975) ${ }^{19}$.

\footnotetext{
${ }^{19}$ The Oxford dictionary of quotations. Oxford: Oxford University Press, 1999.
} 
Os diálogos de Alice com o bichano chamam a atenção dos eruditos. Em certo momento, a menina o indaga sobre como sair do buraco em que se metera. "Para onde você quer ir?", pergunta o gato de Cheshire. Desorientada e sem saber que rumo tomar, Alice diz que não importa o caminho e que só deseja sair daquele lugar. "Então não tem importância o caminho a seguir", replica o estranho animal. Moral da história: se você não sabe aonde quer chegar, qualquer caminho lhe serve. Os especialistas em propriedade intelectual utilizam a expressão "sorriso do gato de Cheshire" quando examinam certos aspectos relacionados à preservação dos direitos autorais de uma obra de arte. Porventura uma pintura tenha sido destruída pelo fogo ou os registros de uma obra foram apenas preservados em arquivos digitais, a inexistência da obra original não elimina os direitos autorais. Cópias fotográficas ou imagens digitalizadas de uma pintura famosa seriam as formas evanescentes da estranha criatura de Lewis Carroll.

\section{De Ozma a Serendip}

Personagens da literatura infanto-juvenil também servem de inspiração para designações curiosas, como o "Projeto Ozma". Ele foi criado em 1960 pelo astrônomo Frank D. Drake, da Universidade de Cornell, e é parte integrante do SETI (Search for Extraterristrial Intelligence), desenvolvido pela NASA. Com efeito, um poderoso radiotelescópio de $24 \mathrm{~m}$ de diâmetro foi posicionado em direção às estrelas Tau Ceti e Epsilon Eridoni para detectar ondas de rádio que sinalizem existência de vida inteligente fora do Sistema Solar. Drake também é conhecido por seus cálculos matemáticos que apontam as chances de um possível contato com civilizações extraterrestres - os adeptos das teorias ufológicas não gostam nem de ouvir falar em seu nome, pois a equação de Drake aponta que as chances são reduzidíssimas ou beiram as fronteiras do impossível! A idéia de batizar o seu projeto foi uma forma encontrada para homenagear a Princesa Ozma, dirigente do reino de Oz - "terra distante, difícil de lá chegar e que é habitada por seres estranhos e exóticos". A personagem foi criada por L. Frank Baum (1956-1919) e está presente na série $O$ mágico de $O z$, histórias que encantam as crianças do mundo inteiro. As crianças ficavam intrigadas sobre como Baum sabia tantos detalhes do reino da Princesa Ozma, mas ele não sonegou informações aos pequenos leitores: ele dizia que utilizava ondas de rádio para se "informar" das novidades que ocorriam no distante reino de Oz e relatava tudo em suas novas histórias. As crianças adoravam. Baum e Lewis Carroll tinham enorme apreço pelos avanços do conhecimento científico e suas historietas são estimulantes a todas as idades. 
Outra terminologia interessante foi criada por Murray Gell-Mann, físico teórico (Prêmio Nobel em Física, 1969). Ele dera importantes contribuições para teoria das partículas elementares e foi o criador da palavra quark, hipotética partícula subatômica com carga elétrica fracionária e um dos constituintes fundamentais da matéria. Embora os quarks não possam ser observados diretamente, evidências experimentais comprovaram a validade do conceito. A terminologia foi inspirada numa frase (Three quarks for Muster Mark!) contida num dos livros de James Joyce (Finnegans wake, 1939).

Uma das criaturas da escritora inglesa J.K. Rowling emprestou o seu nome para designar uma espécie de dinossauro que vivera cerca de 66 milhões de anos atrás, o Dracorex hogwartsia. Os autores da descoberta julgaram que a espécie tinha alguma semelhança com o dragão que o personagem homônimo enfrentara em Harry Potter and the Goblet of Fire (2000). Uma vez que o pequeno bruxo estudara magia e feitiçaria na Hogwarts School, daí veio a inspiração para a criação de uma nova nomenclatura científica. A escritora também emprestou o nome para designar um pedregulho espacial, o asteróide Rowling (\#43844). Ele foi descoberto em 2006 por Mark Hammergren, do Adler Planetarium (Chicago/EUA), e a designação foi homologada pela Astronomical Union. As medições do Dr. Hammergren, fã declarado das aventuras de Harry Potter, indicam que o asteróide tem cerca de 2,5 a 5,5km de diâmetro, ele se encontra entre as órbitas de Marte e Júpiter e leva 4,6 anos para completar a órbita em torno do Sol. Outras inspirações infanto-juvenis serão examinadas a seguir.

O reino de Serendip. A história da ciência revela que importantes conquistas científicas ocorreram ao acaso, como a descoberta da penicilina (1928), feito que abriu as portas ao Prêmio Nobel em Fisiologia ou Medicina (1945) a Sir Alexander Fleming (1881-1955), bacteriologista inglês. Os pesquisadores reconhecem a importância da casualidade, mas coube ao fisiologista Walter B. Cannon (1871-1945) a criação de um novo conceito científico: serendipity. A palavra foi extraída da obra de Horace Walpole (171797), escritor inglês que se inspirara num conto infantil do Ceilão (atualmente Sri Lanka) para escrever Os três príncipes de Serendip (1754). Insatisfeitos com a vida e tal como fizera Siddartha Gautama, o Buda, os personagens partem em viagem pelo mundo em busca de algo indeterminado e encontram pelo caminho coisas que nunca imaginaram. A idéia contida na obra de Walpole serviu de inspiração para designar os efeitos da casualidade sobre os avanços científicos e tecnológicos, pois muitas vezes nós nos deparamos com verdadeiros tesouros quando enveredamos por searas desconhecidas. O novo conceito ganhou ampla aceitação e dicionários modernos (e.g., Webster's Unabridged Dictionary, 1996; Dicionário Houaiss, 2001) explicam o significado do léxico Serendip e de suas variações. 
Relatos autobiográficos também descrevem a importância da serendipidade como fator determinante para o sucesso e desenvolvimento de uma carreira profissional (GANS, 2001; PERKINS, 2005).

Barão de Münchhausen. Dois epônimos foram inspirados na atribulada biografia do Barão de Münchhausen (1720-97, nome original: Karl-Friedrich Hieronymus, Freiherr (barão) von Münchhausen), militar alemão que servira como capitão de cavalaria do exército russo. A fama advém de seus relatos inverossímeis sobre sua vida de soldado, caçador e esportista. Uma coleção de suas histórias foi publicada no Vademecum für lustige Leute (1781-83), mas a origem de muitas delas é anterior ao suposto criador, o que indica que elas foram simplesmente copiadas. Traduções para outros idiomas trouxeram mais fama ao barão, pois as histórias foram "adaptadas" e episódios ainda mais mirabolantes foram adicionados.

A tradução do vademecum para o idioma inglês foi feita por Rudolph Erich Raspe (1737-94); ela foi publicada anonimamente e teve o enorme título: Baron Munchausen's narrative of his marvelous travels and campaigns in Rússia (1785). Menos de um ano depois, Gottfried A. Bürguer (1747-94) traduz a obra para o idioma francês, a qual serviu de base para a versão brasileira ${ }^{20}$. Raspe e Bürguer utilizaram desenhos ilustrativos e exageraram ainda mais a personalidade extravagante do barão. Ambos davam a entender que usufruíam de sua amizade e obtiveram consentimento para a publicação dos "relatos biográficos", mas os dois nunca tiveram contato com pitoresco farsante e o recurso serviu apenas para dar alguma credibilidade às histórias mirabolantes.

O barão não parava quieto e as versões descrevem suas visitas à França, Inglaterra e Oriente Médio. Numa de suas "viagens" à Lua, ele deu uma ajudazinha aos habitantes nas batalhas travadas contra os invasores do Sol. O barão também utilizou suas habilidades na luta da independência dos EUA, ocasião em que ele sofrera um curioso acidente. Entre uma batalha e outra, ele tivera a imprudência de repousar no interior de um canhão, o qual fora inadvertidamente acionado com ele dentro. Ele foi lançado em direção às tropas inglesas, mas teve presença de espírito de se agarrar, em pleno vôo, a uma bola de ferro lançada pelos canhões dos inimigos, feito que permitiu que ele retornasse ileso ao ponto de partida. Os leitores são induzidos a acreditar que a valentia do barão foi vital para a vitória dos americanos, pois nem mesmo um terrível acidente lhe tirou o ânimo para novas refregas. Certa ocasião, uma pesada haste de navio cai sobre a sua cabeça, afundando-a no tórax. Ele continua a lutar bravamente, para espanto de seus companheiros, pois ele sabia que aquilo não era motivo de preocupação: a cabeça retornaria à posição original em alguns dias.

${ }^{20}$ G.A. Burger. Aventuras do barão de Münchhausen. Trad. De M.W. de Castro. Belo Horizonte e Rio de Janeiro: Villa Rica, 1999. Nota: a grafia inglesa simplificou o nome do barão, mas as antigas traduções revelam que o correto era e continua sendo Münchausen. É claro que os especialistas alemães também não gostam da simplificação (ver REICHART \& GROTE, 2001). 
O curioso personagem serviu de inspiração para designar duas modalidades de perturbação mental.

O epônimo síndrome de Münchhausen foi criado em 1951 por Sir Richard A.J. Asher (1951), médico inglês que reconheceu os artefatos nosológicos em alguns de seus pacientes. Com o intuito de chamar a atenção para si, a pessoa simula os sintomas de uma doença cardiovascular (cardiopathia fantastica), falsifica laudos médicos ou cria estratagemas para induzir o diagnóstico de doenças inexistentes, como adicionar sangue na urina (haemorrhagica histrionica). Lesões auto-infringidas na cabeça, face, pescoço ou nas mãos (dermatitis artefacta) também são comuns e a localização no corpo indica o desejo de conferir visibilidade à "doença". A pessoa utiliza material variado para provocar as lesões, como objetos metálicos, silicone líquido e substâncias oleosas; em casos extremos, as fezes ou urina são utilizadas para provocar infecções nos ferimentos.

A síndrome de Münchhausen requer muita atenção dos especialistas, pois ela expõe o indivíduo a riscos desnecessários e as consultas freqüentes congestionam os serviços de saúde. Trata-se de uma enfermidade mental de difícil tratamento, pois médicos experientes são facilmente iludidos com a estrutura lógica das histórias (pseudologia fantastica), embora elas só tenham substrato na mente perturbada da pessoa (DIEFENBACHER \& HEIM, 1997; TURNER \& REID, 2002; HUFFMAN \& STERN, 2003). Alguns estudos descrevem problemas orais ou dentais (e.g., luxações do maxilar, sangramentos das gengivas e mutilações dentárias) e um paper alertou os dentistas de Nova York acerca de um paciente que recorria regularmente a 25 especialistas para tratar de problemas imaginários (ver REICHART \& GROTE, 2001). O impacto econômico também deve ser lembrado, pois os registros descrevem que um paciente recorreu 542 vezes aos serviços de 84 hospitais, durante um período de 12 anos, para tratar suas "doenças"; os custos hospitalares foram estimados em US\$ 718.700, cerca de R \$ 1,2 milhões (ver TURNER \& REID, 2002).

A nomenclatura científica encontrou ampla aceitação na comunidade científica, mas Roy Meadow (1977), pediatra inglês, percebeu uma variação da enfermidade: a "síndrome de Münchhausen por procuração". Com efeito, ela envolve a fabricação, indução ou maximização dos sintomas de uma doença numa criança. Geralmente é a própria mãe que se envolve em tais procedimentos, com o propósito de chamar a atenção para si através da "doença" da criança; estima-se que $90 \%$ dos abusos são perpetrados pelas mães, $5 \%$ por outras mulheres e 5\% pelos pais biológicos (THOMAS, 2003). Os especialistas consideram que se trata de uma forma grave de abuso infantil e apontam os principais indícios da síndrome: 1) a criança apresenta uma doença que é simulada ou produzida pelos pais ou um parente próximo, 2) a criança é desnecessariamente submetida a exames, tratamentos ou procedimentos médicos variados, 
3) os pais alegam que desconhecem a natureza e as causas da "enfermidade" e 4) os sinais e sintomas da "enfermidade" desaparecem ou diminuem quando a criança é removida do ambiente doméstico.

$\mathrm{O}$ agente perpetrador geralmente tem nível educacional superior ao da vítima ou têm treinamento em serviços de saúde, o que permite induzir falsos diagnósticos e enfrentar os argumentos de uma equipe médica (THOMAS, 2003; BARTSCH et al., 2003; BASS \& JONES, 2006). A descoberta da farsa provoca forte reação emocional no agente perpetrador, como foi descrito num episódio ocorrido na Alemanha. Com efeito, foi constatado que uma jovem mãe inoculara sistematicamente microorganismo da flora intestinal (Enterobacter clocae, presente nas fezes) no local do braço onde o seu bebê de 20 meses fora vacinado. O bebê sofreu uma severa e duradoura infecção e foi submetido a várias cirurgias, sem sucesso. Os médicos ficaram intrigados com a resistência da infecção ao tratamento e passaram a desconfiar da mãe, a qual tinha treinamento em enfermagem. Eles obtiveram autorização judicial para filmar secretamente o seu relacionamento com o bebê durante as visitas ao hospital e logo comprovaram que as suspeitas tinham fundamento. Diante da descoberta da farsa, a mãe se tranca no banheiro do hospital e comete suicídio (corta os pulsos com lâminas de bisturi). A autópsia revelou que a jovem mãe tinha sinais de ferimentos auto-infringidos, indício de que ela própria padecera da síndrome de Münchhausen (VENNEMANN et al., 2006).

Estudos posteriores revelaram que idosos ou doentes mentais também podem ser vítimas da síndrome de Münchhausen por procuração (LIBOW, 1995). Com efeito, um estudo revelou que um homem de 69 anos fora vítima de abusos praticados por sua companheira, uma ex-enfermeira de 55 anos. Influenciado por suas opiniões e em razão dos sintomas fabricados, o homem fora induzido a buscar ajuda hospitalar para tratar "enfermidades" variadas, como hemorragia retal, degeneração óssea, dermatites e problemas neurológicos (SMITH \& ARDEN, 1989). Outras investigações revelam que animais de estimação (cães e gatos, principalmente) também são vítimas dos portadores desse distúrbio. Os especialistas apontam alguns sinais: mudanças constantes de veterinário, ferimentos ou infecções que resistem ao tratamento, envenenamentos "acidentais" e preocupação excessiva dos proprietários com a saúde de seus pets (MUNRO \& THRUSFIELD, 2001; TUCKER et al., 2002).

Síndrome de Rapunzel. Ou tricotilomania, distúrbio que leva o paciente a arrancar os próprios cabelos (geralmente do escalpo, mas também das sobrancelhas, pernas, axilas ou da região púbica). Um dos personagens dos irmãos Grimm foi utilizado como referência para a nova nomenclatura científica. Para relembrar: Rapunzel era uma jovem que ostentava uma vasta cabeleira e despendia uma boa parte do tempo penteando-a. Aos doze anos, ela foi encarcerada numa torre por uma bruxa. O único acesso à torre era através das tranças da mocinha, 
as quais eram lançadas como se fossem cordas quando o príncipe ou a ardilosa bruxa solicitava: "Rapunzel, Rapunzel, solte suas tranças". A historieta não revela os motivos que conduziam o príncipe à torre, mas as tertúlias eram freqüentes e se alongavam noite adentro.

A síndrome de Rapunzel ocorre mais freqüentemente em meninas e geralmente emerge no início da adolescência. A tricotilomania ocorre em 0,6 a $1,6 \%$ da população e, entre os que exibem o distúrbio, cerca de $30 \%$ praticam a tricofagia (comer os cabelos após o arrancamento); os sintomas mais comuns são falta de apetite e perda de peso, dores abdominais, vômitos, constipação, severa flatulência, halitose e arrotos com odor desagradável (ver BOWER \& STEIN, 1998; DeBACKER et al., 1999; RAMADAN et al., 2003). Uma vez que os movimentos peristálticos não eliminam por completo os fios de cabelo, o material se acumula e forma uma longa trança no estômago e duodeno - as "tranças de Rapunzel". Cerca de $1 \%$ dos pacientes necessitam de cirurgia para remoção da massa de cabelos (tricobezoar) que se forma no estômago e duodeno (FREY et al., 2005); restos de alimento ficam retidos no emaranhado de cabelos, facilitando a proliferação de bactérias e complicações intestinais. Além dos problemas nutricionais e dos riscos de graves infecções, as imagens tomográficas do tricobezoar às vezes induzem falsos diagnósticos de neoplasma, para desespero dos pais. Os pesquisadores da Escola de Medicina da UNIFESP registraram um caso fatal ocorrido com uma menina de 5 anos que teve perfuração do íleo ocasionada pelo tricobezoar (VENTURA et al., 2005).

Peter Pan e Wendy. Epônimos que aludem à Peter Pan, habitante da Terra do Nunca que nunca envelhecia, e a parceira Wendy. Ambos são personagens do livro Peter Pan (1904), do escritor inglês Sir James M. Barrie (18601937). A designação síndrome de Peter Pan foi criada pelo psicólogo Dan Kiley (1983) para explicar o suposto comportamento irresponsável de homens adultos. O fenômeno é marcado por apelos às fantasias, impulsividade, narcisismo, pensamento disperso, instabilidade nos empregos e uma certa aversão aos compromissos sociais; trata-se de uma dificuldade na transição da adolescência para a vida adulta. Os homens adotam o vestuário, agem ou se expressam de forma semelhante aos adolescentes, recorrem aos produtos farmacológicos (pílulas antioxidantes, cremes rejuvenescedores e suplementos vitamínicos, por exemplo) ou se submetem a cirurgias estéticas, implantes de cabelo e lipoaspirações para ocultar os sinais de envelhecimento. É natural e saudável que os homens exibam preocupação com a aparência física, mas tudo é exagerado na síndrome de Peter Pan.

Alguns especialistas reconhecem que não se trata de um distúrbio do desenvolvimento ou da personalidade, tampouco dispomos de um conceito que possa ser aplicado às mulheres que se "recusam a crescer". Entretanto, 
uma matéria jornalística mostrou o comportamento de mulheres brasileiras que saem à noite, acompanhadas de suas filhas, para visitar casas noturnas. Elas se envolvem em namoricos eventuais com os amigos das filhas, muitas vezes com idade 20 a 30 anos inferior ao da "distinta senhora". Mães não são mães, mas "amigas", e uma delas chegou a admitir que "a moçada diz que eu tenho síndrome de Peter Pan" (Veja, 29 de Março/2006). Namoricos de cinqüentonas com jovens da mesma faixa etária que a das filhas podem ser vistos como algo moderno ou frutos dos novos costumes, mas é preciso uma boa dose de espírito liberal para não se estranhar com o fenômeno, mais ainda se o jovem for amigo da filha da mulher. O relacionamento geralmente tem curta duração, devido às pressões familiares ou incompatibilidade nos papéis sociais. O namorico pode melhorar a auto-estima das mulheres ou pode trazer algum benefício ao rapaz (treinamento em abordagens amorosas ou alguma vantagem material), mas dificilmente ele resulta num casamento formal ou é solidificado com a vinda de filhos. É interessante relembrar a última obra de Thomas Mann (Die betrogene, 1953), pois ela examina os efeitos da disparidade etária na alma feminina.

Wendy é o oposto de Peter Pan, pois ela é uma garota que adota uma atitude de mulher responsável e que se sacrifica em prol de seu parceiro. Leitores atentos logo percebem que ela também é responsável pela imaturidade de Peter Pan, pois ele sabe que a amiga sempre virá em seu socorro nos momentos de aperto. O "dilema de Wendy" está relacionado ao comportamento de mães e esposas, pois muitas mulheres deixam de agir em benefício próprio e se auto-sacrificam em prol dos maridos e filhos; elas superprotegem os filhos e agem como se fossem mães de seus parceiros (KILEY, 1984). As "modernas wendies" enfrentam um dilema no ambiente familiar: a preservação ou anulação da identidade pessoal em prol dos maridos e dos filhos. Caso as mulheres oscilem em direção ao comportamento de Wendy, os sinais são facilmente detectáveis: as "wendies" invariavelmente assumem os erros que não são delas, sentem-se sobrecarregadas com os afazeres domésticos, mas nada fazem para corrigir o problema, aceitam ou se colocam numa posição de inferioridade nas discussões familiares, protegem ou interferem em favor dos maridos nas discussões destes com os familiares (chegam a competir com as sogras), enaltecem excessivamente os maridos, agem como simples serviçais e se submetem ao intercurso sexual mesmo diante da inexistência de vontade. Muitas vezes, amigos e familiares exibem compaixão pela atitude autopunitiva das "wendies", mas parece que a comiseração funciona como combustível para o distúrbio.

Síndrome de Mr. Pickwick. Alguns personagens dos cartoons de Walt Disney exibem perturbações do sono (e.g., pesadelos, convulsões noturnas, sonambulismo e sonolência diurna) e tais peculiaridades servem para enfatizar 
a comicidade das histórias (IRANZO et al., 2007); os enredos também exploram o nanismo psicogênico (síndrome de Kaspar Hauser) e problemas respiratórios pouco conhecidos, como a maldição de Ondina (ver GUERRA, 2005, 2009). Os livros de Charles Dickens (1812-70) também descrevem perturbações do sono e graves enfermidades mentais de seus personagens. $\mathrm{O}$ escritor inglês cultivava interesse pelos avanços da medicina, algo que transparece em suas descrições realísticas sobre distonias, perturbações do sono e crises epilépticas (COSNETT, 1994; WHITELAW \& BLACK, 2000). A síndrome de Mr. Pickwick tem como referência um personagem homônimo do livro The posthumous papers of the Pickwick Club (1836-37).

A síndrome de Mr. Pickwick foi identificada por Burwell e colaboradores (1956). Basicamente, ela descreve a relação entre sobrepeso e dificuldades respiratórias durante o sono. Indivíduos com excesso de peso geralmente exibem sonolência diurna, tal como supostamente ocorria com Mr. Pickwick; a hipoventilação persiste durante o estado de vigília, fato que agrava ainda mais o quadro clínico. O fenômeno resulta em hipertensão pulmonar (cor pulmonale) e está associado a elevadas taxas de mortalidade em crianças com sobrepeso corporal; o problema se agrava durante o sono, pois as interrupções do fluxo respiratório (apnéias) podem resultar em morte (UEMURA et al., 2000; McCALLUM \& SMITH, 2005; OLSON \& ZWILLICH, 2005).

Alguns especialistas e admiradores da obra de Dickens não ficaram satisfeitos com a "homenagem" a Mr. Pickwick. Eles argumentaram que Mr. Pickwick nunca manifestara os principais sintomas da enfermidade (i.e., letargia, falta de ar, cansaço físico e apetite exagerado), mas era exatamente o oposto: a energia the transbordava e o seu amor pela natureza o conduzia a longas caminhadas. Uma carta foi enviada à prestigiosa Human Pathology apontando que os criadores do epônimo confundiram o energético Mr. Pickwick com Joe, o jovem que verdadeiramente exibia os sintomas do distúrbio: era um gorducho de face rosadas, mandrião que só despertava de seus cochilos nas horas das refeições. Isso revela que os leitores são atentos às idiossincrasias dos personagens e não perdoam as injustiças. O distúrbio ficou erroneamente associado a Mr. Pickwick, mas deveria ter nova designação: "síndrome de Joe" ou "síndrome de Burwell" (HASSEL, 1997).

Efeito Cinderela. As vicissitudes enfrentadas por Cinderela também servem como metáfora para explicar o relacionamento conflituoso da criança com um adulto não-aparentado (padrasto ou madrasta). Existem incontáveis versões, mas basicamente as histórias descrevem as agruras que a personagem sofrera nas mãos de uma madrasta. Cinderela lutara para escapar de seus infortúnios e depositara todas as esperanças de um futuro melhor no casamento com um príncipe. Madrastas são personagens marcantes das histórias infantis e elas estão associadas quase que invariavelmente a maus-tratos, negligência, 
rivalidades e até mesmo infanticídio. Padrastos são figuras apagadas ou quase inexistentes nas histórias e o viés feminil revela o mundo trágico das mulheres de tempos remotos. Com efeito, a dissolução do casamento só ocorria em circunstâncias especiais (infertilidade ou dúvidas sobre a virgindade da jovem), de forma que a proliferação de madrastas era resultante da morte das mães. Muitas mulheres morriam quando davam à luz ou logo após a parturição, em conseqüência da imaturidade física, inexperiência materna, hemorragias e infecções oportunísticas (febre puerperal).

"Efeito Cinderela" é um conceito recente da psicologia evolucionária e está relacionado à teoria do investimento parental. No contexto familiar, o fenômeno diz respeito ao conflito entre uma criança e um adulto não-aparentado, geralmente uma mulher. $\mathrm{O}$ conflito emerge quando os recursos são escassos e a mulher em plena capacidade reprodutiva (madrasta) tem que optar entre alocar recursos energéticos aos próprios filhos ou a uma prole alheia (DALY \& WILSON, 1999). Os prejuízos recaem sobre as crianças não-aparentadas, como podemos notar nas histórias infantis, as quais descrevem infanticídios, maus-tratos e negligência parental (GUERRA, 2009). Estudos bem conduzidos revelam que enteados e enteadas com menos de 5 anos são mais vulneráveis a acidentes fatais (e.g., quedas e afogamentos) que filhos legítimos (TOOLEY et al., 2006).

Conflito parental é um fenômeno amplo e complexo, pois envolve o relacionamento de crianças de ambos os sexos com homens e mulheres adultos. A literatura infantil contem um nítido viés feminil, pois os enredos basicamente descrevem os infortúnios de uma menina órfã nas mãos de uma madrasta, enquanto o verdadeiro pai se mantêm distante ou é figura apagada. Entretanto, diversos estudos sobre o efeito Cinderela descrevem que a natureza e intensidade do conflito parental dependem da idade das crianças, bem como do sexo destas e dos adultos não-aparentados. Com efeito, as meninas usualmente são negligenciadas ou são alvos de humilhações e maus-tratos por parte das madrastas, mas podem ser abusadas sexualmente quando interagem com padrastos - fenômeno que às vezes é designado "efeito Lolita" (alusão ao livro homônimo de Vladimir Nabokov, 1958). Por outro lado, meninos órfãos podem ser espancados pelos padrastos ou negligenciados pelas madrastas; quando ganham idade, os garotos e rapazes ganham capacidade física de reação aos abusos, mas a maturidade física das mocinhas torna-as ainda mais susceptíveis aos abusos sexuais por parte dos padrastos. Os enredos das histórias infantis revelam que as menininhas de outrora viviam, na verdade, num mundo triste e cinzento.

Complexo de Cinderela. Conceito formulado por Collete Dowling (The Cinderella complex, 1981), tendo como referência as historietas de Charles Perrault e dos irmãos Grimm. O culto à Cinderela é um fenômeno marcante, 
como demonstram os filmes de Hollywood, cartoons, programas de TV e concursos de beleza (KELLEY, 1994; WATSON \& MARTIN, 2000; OTNER \& PLECK, 2003). Collete Dowling realizou entrevistas com mulheres de diferentes idades e profissões e mergulhou numa pesquisa bibliográfica para extrair suas conclusões acerca da emancipação feminina. $\mathrm{O}$ seu livro se tornou best seller nos EUA e permaneceu várias semanas na lista do New York Times entre os mais vendidos. Trata-se de uma forma de dependência psicológica ou suposto desejo inconsciente das mulheres por cuidados de outrem, algo que torna as mulheres agrilhoadas e dependentes dos homens. O fenômeno foi definido como resultante de "uma rede de atitudes e temores profundamente reprimidos que retém as mulheres numa espécie de penumbra e as impede de utilizar plenamente seu intelecto e sua criatividade" (DOWLING, 1981).

O sonho de Cinderela ainda incendeia o imaginário feminino e ele se manifesta no ritual de noivado e casamento: uma aliança de ouro sela o compromisso entre homem e mulher e o consórcio matrimonial geralmente ocorre em maio, o mês das noivas. Por mais anacrônico que seja, as mulheres sonham com o casamento em "véu e grinaldas" e desejam que a união formal ocorra numa igreja, sob as bênçãos de um padre. A festa de casamento deve ser inesquecível, documentada num álbum de fotografias, e a modéstia de recursos cede lugar aos esbanjamentos e extravagâncias. É nesse momento que a noiva tem o direito a um baile de Cinderela, tendo como par o que ela imagina ser o príncipe encantado. Entretanto, o enredo da vida real parece ocorrer de trás para frente, pois logo em seguida surgem as faturas dos cartões de crédito, os aborrecimentos e a monotonia da vida doméstica. A Cinderela se depara com uma terrível transformação: o que ela julgava ser o seu príncipe encantado é, na verdade, um horrendo sapo! As feministas esclarecem que o sonho de Cinderela é uma armadilha, pois ele impede o crescimento intelectual, a auto-suficiência e a plena emancipação das mulheres.

“Dilema de Cinderela". É outro curioso epônimo relacionado ao universo das histórias infantis. Trata-se de um conflito vivenciado por mulheres bem sucedidas na vida profissional (e.g., empresárias, advogadas e professoras universitárias). A dura jornada de trabalho e a competição desenfreada são prejudiciais às "modernas cinderelas", pois o investimento na carreira conflita com o desejo de atingir a plenitude feminina (i.e., casamento, filhos e constituição de uma família). Quando a carreira profissional é colocada em primeiro plano, o casamento é postergado e a maternidade às vezes é inviabilizada pelos avanços da idade, ocasionando uma intensa frustração nas "cinderelas" com mais de 30 anos (HEWLETT, 2002). 
Os problemas das "cinderelas" não se restringem ao desconforto emocional ou frustrações profissionais. É preciso reconhecer que elas enfrentam uma dupla jornada de trabalho, pois devem conciliar as responsabilidades no emprego com os afazeres domésticos. O estresse, a alimentação inadequada e as dificuldades na manutenção do peso corporal resultam em graves problemas cardiovasculares, fenômeno que os médicos informalmente conhecem como "doença de Cinderela". Porventura, essas mulheres sejam casadas e tenham filhos, o investimento na carreira profissional pode ocasionar conflitos conjugais e dificuldades no relacionamento com os filhos; quando mulheres inteligentes e auto-suficientes optam por valorizar o casamento e a formação da família, elas podem cair na armadilha descrita anteriormente: o "dilema de Wendy" e o "complexo de Cinderela". O modo como as mulheres enfrentam tais adversidades depende muito das circunstâncias e dos traços de personalidade.

\section{Palavras finais}

O consórcio intelectual entre ciência e literatura é produtivo e tem rendido bons frutos nas duas searas. Relatos literários descrevem o conhecimento científico da época e isso pode ser visto nas obras de Shakespeare e Luís de Camões; a teoria das sete esferas e o interior da terra, onde se situava os degraus que davam acesso às regiões infernais, foram exploradas por Virgilio (Eneida, 70 a.C.) e Dante Alighieri (Divina commedia, 1308-21). Nós também dispomos de relatos acerca de momentos históricos, como a epidemia de tifo que ceifou incontáveis vidas humanas e alterou o cenário político e religioso da Europa; os efeitos sociais e o desespero da população foram descritos por Boccaccio e Daniel DeFoe.

Em outros tempos, as teorias científicas eram publicadas como se fossem obras literárias. Os livros traziam diálogos com personagens (reais ou imaginários) e exibiam estrutura condizente com o nível de discernimento do cidadão comum; estes recursos foram adotados por Galileu e Isaac Newton. Certos avanços do conhecimento despertam debates públicos, em razão do próprio assunto ou porque idéias arrojadas foram aglutinadas num livro elegante e bem escrito. Quando isso ocorre, nós nos deparamos com uma dúvida: trata-se de uma contribuição científica ou de uma obra literária? Geralmente, nós temos uma boa mistura dos ingredientes, como ocorreu com On the origin of species (1859). Com efeito, o naturalista Charles Darwin adotou um estilo literário para divulgar suas idéias e seu livro se tornou um best-seller. Algumas damas ficaram escandalizadas com as novas postulações e torciam para que elas não passassem de equívocos, mas, caso a teoria fosse consistente, não seria conveniente divulgar ao mundo que os ingleses descendiam de "macacos". 
Um debate foi promovido pela British Association for Advancement of Science (1860) e o bispo Samuel Wilberforce (1805-73) encontrou oportunidade para lançar um petardo em direção à T.H. Huxley, notável defensor da teoria: What it through his grandfather or his grandmother that he claimed his descent from a monkey? (Oxford dictionary of quotations, 1999). É isso: os avanços do conhecimento científico inspiram discussões variadas e até rendem boas piadas.

Qual é a utilidade do conhecimento científico? Um equívoco bastante comum é imaginar que a estrutura lógica, a linguagem precisa e o reducionista científico sejam incompatíveis com a criação literária. Nós temos vários exemplos que provam o contrário. Com efeito, bons engenheiros e bons matemáticos produziram obras literárias inesquecíveis, como Euclydes da Cunha e Lewis Carroll; a lista é ampla, mas o exemplo mais interessante é o "detetive científico" Sherlock Holmes. Também existem os romances documentais, os quais exibem as qualidades de um relatório científico e magnetizam as atenções de leitores exigentes. São exemplos dessa categoria os livros que descrevem a gênese do fanatismo religioso (Padre Ambrosio Schüpp e M.B. Lourenço Filho) e as impressionantes descrições dos gulags soviéticos (Alexander Solzhenitsyn, Prêmio Nobel de Literatura/1970). É importante ressaltar que cientistas e vários homens das letras compartilham interesses por fenômenos naturais, perturbações mentais e o relacionamento com o meio ambiente. Além do valor histórico, algumas obras literárias descrevem enfermidades pouco conhecidas e outras que perderam importância com os avanços da ciência. Nesse sentido, os historiadores da medicina lêem com especial interesse a produção literária de Luis de Camões (escorbuto), Samuel Pepys (estresse pós-traumático) e J. Guimarães Rosa (febre amarela), pois entendem que elas não se prestam apenas ao entretenimento. A exploração do conhecimento científico também rende bons frutos na seara da literatura infantil, como atestam as historietas de L. Frank Baum e as extravagâncias de Lewis Carroll.

Qual é a utilidade da boa literatura? Alguns romancistas escreviam como se fossem especialistas em enfermidades mentais e tinham apreço pelos avanços do conhecimento científico, diferentemente do gênero sci-fi que muitas vezes exagera nas profecias de fim do mundo ou fazem entender que epidemias e tragédias ambientais são resultantes da "ambição desenfreada" dos cientistas. A humanidade corre o risco de extinção, em razão de experiências laboratoriais e surgimento de monstros tecnológicos (e.g., robôs, andróides e super-computadores); o cidadão comum é induzido a acreditar que cientistas e inventores são portadores de graves perturbações mentais e, com efeito, a cretinização é levada ao extremo nos cartoons infantis - o "cientista louco" é personagem quase obrigatório! Alguns romancistas e poetas tinham uma percepção mais sofistica a respeito do conhecimento científico ou tinham formação em Medicina e usaram suas habilidades para criação literária, como o russo Tchekhov e o mineiro Pedro Nava (1903-84). 
Anamnese é um conceito bastante conhecido dos profissionais que atuam nos serviços de saúde. Basicamente, é o registro claro e preciso acerca do surgimento e evolução de uma enfermidade, sem a preocupação com diagnósticos e prognósticos. Poetas e romancistas às vezes usam uma técnica parecida para descrever o sofrimento humano e os resultados são surpreendentes. Relatos literários devem ser valorizados por motivos variados, pois eles tratam de enfermidades pouco conhecidas e o estilo rebuscado revela aspectos que geralmente escapam de um relatório técnico. Alguns escritores recorriam aos papers, consultavam os periódicos ou buscavam a opinião de especialistas para fundamentar os traços de personalidade ou para descrever os sintomas de uma doença; é o que poderíamos designar de "dissecação espiritual". Esses relatos literários são úteis para a formação dos profissionais dos serviços de saúde, pois a vida atribulada, as pressões por rapidez e eficiência (i.e., muitos pacientes, poucos especialistas) e os recursos tecnológicos conduzem àquilo que vagamente conhecemos como "desumanização" da medicina. Com efeito, algumas instituições universitárias utilizam obras literárias com propósitos variados, pois o exercício literário (leitura e estímulos à redação de textos) melhora a qualidade dos relatórios técnicos, amplia a capacidade observacional dos sinais e sintomas de uma enfermidade e, mais importante, é uma forma segura de se cultivar a empatia em relação ao sofrimento humano.

\section{Referências bibliográficas}

AMANCIO, E.J. Dostoievsky and Stendhal's syndrome. Arquivos de neuropsiquiatria, 63(4): 1099-1103, 2005.

ASHER, R. Munchausen's syndrome. The lancet, 1: 339-41, 1951.

ATKINSON, R.A. \& APPENZELLER, O. "Deer woman". Headache, 17(6): 229-32, 1978.

BAR-EL, Y.; DURST, R.; KATZ, G.; ZISLIN, J.; STRAUSS, Z. \& KNOBLER, H.Y. Jerusalem syndrome. The british journal of psychiatry, 176: 86-90, 2000.

BARTSCH, C.; RIßE, M.; SCHÜTZ, H.; WEIGAND, N. \& WEILLER, G. Munchausen syndrome by proxy (MSBP): an extreme form of child abuse with a special forensic challenge. Forensic Science International, 137: 147$51,2003$.

BASS, C. \& JONES, D.P.H. Fabricated or induced illness. Psychiatry, 5(2): 60-65, 2006. 
BELL, W.G. The great plague in London. Londres: The Folio Society, 2001. BILAVSKY, E.; YARDEN-BILAVSKY, H. \& ASHKENAZI, S. Literature names for pediatric medical conditions. Acta padiatrica, 96: 975-78, 2007.

BOKEY, K. \& WALTER, G. Literature and psychiatry: the case for a close liaison. Australasian psychiatry, 10(4): 393-99, 2002.

BOWER, C. \& STEIN, D. Trichobezoars in trichodillomania: a case report and literature overview. Psychosomatic medicine, 60(5): 658-60, 1998.

BURNS, A.; GALLAGLEY, A. \& BYRNE, J. Delirium. Journal of neurology, neurosurgery, and psychiatry, 75: 362-67, 2004.

BURWELL, C.S.; ROBIN, E.D.; WHALEY, R.D. \& BICKELMANN, A.G. Extreme obesity associated with alveolar hypoventilation: a Pickwickian syndrome. The american journal of medicine, 21: 811-18, 1956.

BYWATERS, E.G.L. The Cheshire cat syndrome. Postgraduate medical journal, 44: 19-22, 1968.

CLARK, A. Lewis Carroll-a biography. Nova York: Schocken Books, 1979.

COHEN, M.N. Lewis Carroll - a biography. Nova York: Alfred A. Knopf, 1995.

COSNETT, J.E. Charles Dickens and epilepsy. Epilepsia, 35(4): 903-05, 1994.

DALY, M. \& WILSON, M. The truth about Cinderella. Nova York: Yale University Press, 1999.

DeBACKER, A.; van NOOTEN, V. \& VANDENPLAS, Y. Huge gastric trichobezoar in a 10-year-old girl: case report with emphasis in endoscopy in diagnosis and therapy. Journal of pediatric gastroenterology and nutrition, 28(5): 513-15, 1999.

DIEFENBACHER, A. \& HEIM, G. Neuropsychiatry aspects in Munchausen's syndrome. General hospital psychiatry, 19: 281-85, 1997.

DIETL, J. Thomas Mann's last novella "The Black Swan": the tragic story of a post-menopausal woman. European journal of obstetrics \& gynecology and reproductive biology, 113(2): 255-257, 2004.

DOWLING, C. The Cinderella complex. Nova York: Pocket, 1981.

DYER, T.F.T. Folklore of Shakespeare. Williamstown: Corner House Publishers, 1978. 
FALK, R. \& SAMUEL-COHN, E. Lewis Carroll's obtuse problem. Teaching statistics, 23(3): 72-5, 2001.

FREUD, S. A disturbance of memory on the Acropolis. In: Standard edition of the complete psychological works of Sigmund Freud (vol. 22). Londres: Hogarth Press, 1936.

FREY, A.S.; McKEE, M.; KING, R.A. \& MARTIN, A. Hair apparent: Rapunzel syndrome. American Journal of Psychiatry, 162(2): 242-48, 2005.

FURMAN, Y.; WOLF, S.M. \& ROSENFIELD, D.S. Shakespeare and sleep disorders. Neurology, 49: 1171-72, 1997.

GANS, H. Circumstance and serendipity. Surgery, 130(1): 82-84, 2001.

GUERRA, R.F. Sereias, lobisomens e animais no imaginário. Humanidades/ UnB, 51(Maio): 61-82, 2005.

GUERRA, R.F. Doença mental e os estranhos personagens da literatura infantil. Revista de Ciências Humanas, 43(2): 445-89, 2009.

HASSEL, B. Pickwickian syndrome, a misnomer. Human Pathology, 28(11): $1329,1997$.

HEWLETT, S.A. Creating a life. Nova York: Talk Miramax Books, 2002.

HOFFMAN, A. Testing the Red Queen hypothesis. Journal of evolutionary biology, 4: 1-7, 1991.

HUFFMAN, J.C. \& STERN, T.A. The diagnosis and treatment of Munchausen's syndrome. General hospital psychiatry, 25: 358-63, 2003.

IGIC, R. Anton Pavlovich Chekhov (1860-1904). The American journal of psychiatry, 162:12, 2005.

IRANZO, A.; SANTAMARIA, J. \& de RIQUER, M. Sleep and sleep disorders in Don Quixote. Sleep Medicine, 5: 97-100, 2004.

IRANZO, A.; SCHENCK, C.H. \& FONTE, J. REM sleep behavior disorder and other sleep disturbances in Disney animated films. Sleep Medicine, 8(5): 331-36, 2007.

KACHAEVA, M. Russian literature and psychiatry. The british journal of psychiatry, 167(3): 403-06, 1995.

KELLEY, K. A modern Cinderella. Journal of popular Culture, 17(1) 1994. 
KILEY, D. The Peter Pan syndrome: men who have never grown up. Nova York: Dodd Mead, 1983.

KILEY, D. The Wendy dilemma: when women stop mothering their men. Nova York: Arbor House Pub. Co., 1984.

KUMAR, P. \& NARGUND, V. Samuel Pepys: a patient perspective of litothomy in 17th century England. Journal of Urology, 175: 1221-24, 2006.

LARNER, A.J. Lewis Carroll's Humpty Dumpty: an early report of prosopagnosia? Journal of Neurology, neurosurgery \& psychiatry, 75(7): 1063, 2004.

LIBOW, J.A. Munchausen by proxy victims in adulthood: a first look. Child Abuse \& Neglect, 19(9): 1131-42, 1995.

LIPPMAN, C.W. Certain hallucinations peculiar to migraine. Journal of nervous and mental disease, 116: 346-351, 1952.

MAGALHÃES, J.P. de. Alice's dilemma. Futures, 36: 85-89, 2004.

MAGHERINI, G. La syndrome di Stendhal. Milão: Fettrinelli, 1992.

McCALLUM, B.J. \& SMITH, S.M. Ailing allegories and sickly stories: the quest for pathology in children's literature. The medical journal of Australia, 183(11/12): 670-71, 2005.

McEWEN, D.R. Recognizing Munchausen's syndrome. AORN Journal, 67(2): 440-42, 1998.

McKAY, E. English diarists: gender, geography and occupation, 1500-1700. History, 90(298): 191-212, 2005.

MEADOW, R. Munchausen syndrome by proxy: the hinterland of child abuse. The Lancet, 2: 443-45, 1977.

MERTON, R.K. \& BARBER, E. The travels and adventures of serendipity. Princeton: Princeton University Press, 2004.

MUNRO, H.M.C. \& THRUSFIELD, M.V. "Battered pets": Munchausen syndrome by proxies (factitious illness by proxy). Journal of small animal practice, 42: 385-89, 2001.

NAFFINE, N. Who are law's persons? From Cheshire cats to responsible objects. Modern law review, 66(3): 346-67, 2003. 
O'CARROLL, R.E.; MASTERTON, G.; DOUGALL, N.; EBMEIER, K.P.; GOODWIN, G.M. The neuropsychiatry sequelae of mercury poisoning: the Mad Hatter's Disease revisited. The british journal of psychiatry, 167(1): 95-98, 1995.

OLSON, A.L. \& ZWILLICH, C. The obesity hypoventilation syndrome. The American Journal of Medicine, 118: 948-56, 2005.

ÖSTÖRS, A.G. \& PHILLIPS, G.E. Immortal women: essays in medical eponyms: part I. The American Journal of Surgical Pathology, 23(5): 495$501,1999$.

OTNES, C.C. \& PLECK, E.H. Cinderella dreams: the allure of the lavish wedding. Berkeley: University of California Press, 2003.

PAPERNO, I. What can be done with diaries? The Russian Review, 63: 56173, 2004.

PERKINS, H.A. The role of serendipity in the evolution of a career: an autobiography. Transfusion Medicine Reviews, 19(4): 314-17, 2005.

PODOLL, K. \& ROBINSON, D. Lewis Carroll's migraine experiences. The Lancet, 353: 1366, 1999.

PODOLL, K. \& ROBINSON, D. Recurrent Lilliputian hallucinations as visual aura symptom in migraine. Cephalalgia, 21: 990-92, 2001.

PROEHL, J.A. The Cheshire cat of professionals. Journal of emergency nursing, 25: 349-50, 1999.

RAMADAN, N.; PANDYA, N.A. \& BHADURI, B. A Rapunzel with a difference. Archives of disease in Childhood, 88(3): 264, 2003.

REICHART, P.A. \& GROTE, M. Münchhausen syndrome or Munchausen syndrome? Two names - one syndrome. Journal of oral pathology medicine, 30: 510-12, 2001.

RESTAK, R.M. Alice in Migraineland. Headache, 46: 306-11, 2006.

ROSENFIELD, D.B. Do stutterers have different brains? Neurology, 57: 171-72, 2001.

ROTHENBERG, M.B. The dying child. In: J.D. Noshpitz (Editor-in-Chief). Basic handbook of child psychiatry. Pp. 477-82. New York: Basic Books, 1979. 
SANFORD, C. Urban medicine: threats to health of travelers to developing world cities. Journal of Travel medicine, 11: 313-27, 2004.

SCHOTT, G.D. Mirror writing: Allen's self-observations, Lewis Carroll's "looking-glass" letters, and Leonardo da Vinci's maps. The Lancet, 354: 2158-61, 1999.

SCHWARTZ, R.S. Medicine is my lawful wife. The New England journal of medicine, 351: 213-4, 2004.

SMITH, N.J. \& ARDEN, M.H. More sickness than in health: a care of Munchausen syndrome by proxy in elderly. Journal of Family Therapy, 11: 32134, 1989.

SUTCLIFFE, J. \& DUIN, N. A history of medicine. Nova York: Barnes \& Noble Books, 1992.

THOMAS, K. Munchausen syndrome by proxy: identification and diagnosis. Journal of Pediatric Nursing, 18(3): 174-80, 2003.

TODD, J. The syndrome of Alice in Wonderland. Canadian medical association journal, 73: 701-04, 1955.

TOOLEY, G.A.; KARAKIS, M.; STOKES, M. \& OZANNE-SMITH, J. Generalizing the Cinderella effect to unintentional childhood fatalities. Evolution and Human Behavior, 27: 224-30, 2006.

TUCKER, H.S.; FINLAY, F. \& GUITON, S. Munchausen syndrome involving pets by proxies. Archives of Disease in Childhood, 87: 263, 2002.

TURNER, J. \& REID, S. Munchausen's syndrome. The Lancet, 359: 346, 2002.

UEMURA, K.; HARADA, K.; SHIOTANI, A.; KAI, A.; URATA, Y.; YASUHARA, M. \& YOSHIDA, K. Obesity-sleep apnea (Pickwickian) syndrome: autopsy findings and a medicolegal review. Legal Medicine, 2: 36-41, 2000.

URQUHART-HAY, D. The knife and the stone. ANZ Journal of Surgery, 69: 267-75, 1999.

Van VALEN, L. A new evolutionary law. Evolutionary Theory, 1: 1-30, 1973.

VENNEMANN, B.; PERDERKAMP, M.G.; WEINMANN, W.; FALLERMARQUARDT, M.; POLLAK, S. \& BRANDIS, M. A case of Munchausen syndrome by proxy with subsequent suicide of the mother. Forensic Science International, 158: 195-99, 2006. 
VENTURA, D.E.; HERBELLA, F.A.M.; SCHETTINI, S.T. \& DELMONTE, C. Rapunzel syndrome with a fatal outcome in a neglected child. Journal of Pediatric Surgery, 40: 1665-67, 2005.

VOELPEL, S.; LEIBOLD, M.; TEKIE, E. \& Von KROGH, G. Escaping the Red Queen effect in competitive strategy: sense-testing business models. $E u$ ropean Management Journal, 23(1): 37-49, 2005.

VEIN, A.A. Leo Tolstoy's theory of sleep. Sleep Medicine, 2007

WATSON, E. \& MARTIN, D. The Miss America pageant: pluralism, femininity, and Cinderella all in one. Journal of Popular Culture, 34(1): 105-26, 2000.

WHITELAW, W.A. \& BLACK, A.J. Sleep of the great. Respiration Physiology, 119: 209-17, 2000.

WILSON, G.A.; FIELD, A.P. \& FULLERTON, S. The big brown eyes of Samuel Pepys. Archives of Ophthalmology, 120(July): 969-75, 2002.

ZIEGLER, P. The black death. Gloucestershire: Alan Sutton Publishing Limited, 1991. 